GEORGE A. AKERLOF

University of California, Berkeley

PAUL M. ROMER

University of California, Berkeley

\title{
Looting: The Economic Underworld of Bankruptcy for Profit
}

DURING THE 1980s, a number of unusual financial crises occurred. In Chile, for example, the financial sector collapsed, leaving the government with responsibility for extensive foreign debts. In the United States, large numbers of government-insured savings and loans became insolvent-and the government picked up the tab. In Dallas, Texas, real estate prices and construction continued to boom even after vacancies had skyrocketed, and then suffered a dramatic collapse. Also in the United States, the junk bond market, which fueled the takeover wave, had a similar boom and bust.

In this paper, we use simple theory and direct evidence to highlight a common thread that runs through these four episodes. The theory sug-

We would like to give special thanks to James Pierce and William Black. In their capacities as executive director and deputy director of the National Commission on Financial Institutions, Reform, Recovery, and Enforcement, they have been pursuing an independent inquiry into the savings and loan crisis. They have reached many conclusions that we share and they have provided us with much useful corroborating evidence. We are also grateful to Halsey Rogers for invaluable research assistance. Paul Asquith, James Barth, Mark Carey, Roger Craine, Curtis Eaton, Pierre Fortin, Sebastian Edwards, Jeffrey Frankel, Jeffrey Gunther, Bronwyn Hall, Robert Hall, Elhanan Helpman, Richard Lipsey, Ken Rosen, Nate Rosenberg, Edward Safarian, Benjamin Stein, Nancy Wallace, Michael Wolfson, and Janet Yellen gave us useful comments and/or provided us with help in understanding the complexities of unfamiliar areas. None of the assertions we make should be attributed to any of these people, and we alone are responsible for any errors of fact or interpretation. This research was supported by the National Science Foundation, the Canadian Institute for Advanced Research, and the Russell Sage Working Group on Institutions and Development. 
gests that this common thread may be relevant to other cases in which countries took on excessive foreign debt, governments had to bail out insolvent financial institutions, real estate prices increased dramatically and then fell, or new financial markets experienced a boom and bust. We describe the evidence, however, only for the cases of financial crisis in Chile, the thrift crisis in the United States, Dallas real estate and thrifts, and junk bonds.

Our theoretical analysis shows that an economic underground can come to life if firms have an incentive to go broke for profit at society's expense (to loot) instead of to go for broke (to gamble on success). Bankruptcy for profit will occur if poor accounting, lax regulation, or low penalties for abuse give owners an incentive to pay themselves more than their firms are worth and then default on their debt obligations.

Bankruptcy for profit occurs most commonly when a government guarantees a firm's debt obligations. The most obvious such guarantee is deposit insurance, but governments also implicitly or explicitly guarantee the policies of insurance companies, the pension obligations of private firms, virtually all the obligations of large banks, student loans, mortgage finance of subsidized housing, and the general obligations of large or influential firms. These arrangements can create a web of companies that operate under soft budget constraints. To enforce discipline and to limit opportunism by shareholders, governments make continued access to the guarantees contingent on meeting specific targets for an accounting measure of net worth. However, because net worth is typically a small fraction of total assets for the insured institutions (this, after all, is why they demand and receive the government guarantees), bankruptcy for profit can easily become a more attractive strategy for the owners than maximizing true economic values.

If so, the normal economics of maximizing economic value is replaced by the topsy-turvy economics of maximizing current extractable value, which tends to drive the firm's economic net worth deeply negative. Once owners have decided that they can extract more from a firm by maximizing their present take, any action that allows them to extract more currently will be attractive-even if it causes a large reduction in the true economic net worth of the firm. A dollar in increased dividends today is worth a dollar to owners, but a dollar in increased future earnings of the firm is worth nothing because future payments accrue to the creditors who will be left holding the bag. As a result, bankruptcy for 
profit can cause social losses that dwarf the transfers from creditors that the shareholders can induce. Because of this disparity between what the owners can capture and the losses that they create, we refer to bankruptcy for profit as looting.

Unfortunately, firms covered by government guarantees are not the only ones that face severely distorted incentives. Looting can spread symbiotically to other markets, bringing to life a whole economic underworld with perverse incentives. The looters in the sector covered by the government guarantees will make trades with unaffiliated firms outside this sector, causing them to produce in a way that helps maximize the looters' current extractions with no regard for future losses. Rather than looking for business partners who will honor their contracts, the looters look for partners who will sign contracts that appear to have high current value if fulfilled but that will not-and could not-be honored.

We start with an abstract model that identifies the conditions under which looting takes place. In subsequent sections, we describe the circumstances surrounding the financial crisis in Chile and the thrift crisis in the United States, paying special attention to the regulatory and accounting details that are at the heart of our story. We then turn to an analysis of the real estate boom in Dallas, the center of activity for Texas thrifts. We construct a rational expectations model of the market for land in which investors infer economic fundamentals from market prices. ${ }^{1}$ We then show how the introduction of even a relatively small number of looters can have a large effect on market prices.

In the last section, we examine the possible role of looting at savings and loans and insurance companies in manipulating the prices in the newly emerging junk bond market during the 1980s. In contrast to the Dallas land market, where the movements in prices appear to have been an unintended side effect of individual looting strategies, we argue that in the junk bond market, outsiders could have-and may have-coordinated the actions of some looters in a deliberate attempt to manipulate prices. Evidence suggests that this opportunity was understood and exploited by market participants. By keeping interest rates on junk bonds artificially low, this strategy could have significantly increased the fraction of firms that could profitably be taken over through a debt-financed acquisition.

1. For such a model, see Grossman (1976). 
Before turning to the theoretical model, we will place this paper within the context of the large literature that bears on the issues we address. The literature on the thrift crisis has two main strands: popular accounts $^{2}$ and economists' accounts. ${ }^{3}$

In contrast to popular accounts, economists' work is typically weak on details because the incentives economists emphasize cannot explain much of the behavior that took place. The typical economic analysis is based on moral hazard, excessive risk-taking, and the absence of risk sensitivity in the premiums charged for deposit insurance. This strategy has many colorful descriptions: "heads I win, tails I break even"; "gambling on resurrection"; and "fourth-quarter football"; to name just a few. Using an analogy with options pricing, economists developed a nice theoretical analysis of such excessive risk-taking strategies. ${ }^{4}$ The problem with this explanation for events of the 1980 s is that someone who is gambling that his thrift might actually make a profit would never operate the way many thrifts did, with total disregard for even the most basic principles of lending: maintaining reasonable documentation about loans, protecting against external fraud and abuse, verifying information on loan applications, even bothering to have borrowers fill out loan applications. ${ }^{5}$ Examinations of the operation of many such thrifts show that the owners acted as if future losses were somebody else's problem. They were right.

Some economists' accounts acknowledge that something besides excessive risk-taking might have been taking place during the 1980 s. ${ }^{6}$ Edward Kane's comparison of the behavior at savings and loans (S\&Ls) to a Ponzi scheme comes close to capturing some of the points that we emphasize. ${ }^{7}$ Nevertheless, many economists still seem not to understand that a combination of circumstances in the 1980 s made it very easy to loot a financial institution with little risk of prosecution. Once this is

2. The popular books that we have found most useful for understanding the details of what actually took place in several notorious institutions are Adams (1990), Mayer (1990), O’Shea (1991), Pizzo, Fricker, and Muolo (1989), Robinson (1990), and Wilmsen (1991).

3. See, for example, Kane (1989), White (1991), and Brumbaugh, Carron, and Litan (1989).

4. See Merton (1978).

5. Black (1993b) forcefully makes this point.

6. See, for example, Benjamin Friedman's comments on the paper by Brumbaugh, Carron, and Litan (1989).

7. Kane (1989). 
clear, it becomes obvious that high-risk strategies that would pay off only in some states of the world were only for the timid. Why abuse the system to pursue a gamble that might pay off when you can exploit a sure thing with little risk of prosecution?

Our description of a looting strategy amounts to a sophisticated version of having a limited liability corporation borrow money, pay it into the private account of the owner, and then default on its debt. There is, of course, a large literature in corporate finance that emphasizes the strategies that equity holders can use to exploit debt-holders when shareholders have limited liability ${ }^{8}$ We have nothing to add to the analysis of this problem in the context of transactions between people or firms in the private sector. The thrust of this literature is that optimizing individuals will not repeatedly lend on terms that let them be exploited, so if lending occurs, some kind of mechanism (such as reputation, collateral, or debt covenants) that protects the lenders must be at work.

However, this premise may not apply to lending arrangements undertaken by the government. Governments sometimes do things that optimizing agents would not do, and, because of their power to tax, can persist long after any other person or firm would have been forced to stop because of a lack of resources.

\section{An Abstract Model of Looting}

A simple three-period model can capture the main points in the analysis of bankruptcy for profit. In this section, we use it to establish three basic results. First, limited liability gives the owners of a corporation the potential to exploit lenders. Second, if debt contracts let this happen, owners will intentionally drive a solvent firm bankrupt. Third, when the owners of a firm drive it bankrupt, they can cause great social harm, just as looters in a riot cause total losses that are far greater than the private gains they capture.

We warn the reader that our approach in setting up the model in this section differs from the approach used in most other examinations of contracts. The typical analysis starts with a description of an economic environment and characterizes efficient contracts. Inefficient contracts are presumed not to arise in the market, or at least not to persist for long.

8. See, for example, Brealey and Myers (1984, pp. 501-03). 
We start from the assumption that the relevant creditor, the government, agrees to an inefficient contract and can persist in it for some time. We offer no explicit theory of why the government does this. Our goal in the body of the paper is merely to characterize the private sector behavior that the inefficient government contracts and regulations can induce. Only in the conclusion do we hint at the more complicated question of why governments do what they do.

In addition to assuming that contracts are inefficient, our basic model relies on perfect certainty and the presence of legal strategies for looting. Perfect certainty makes the models simpler, but more importantly, it yields a starker contrast between the looting (go broke) strategies that we emphasize and the subsidized risk-taking (go-for-broke) strategies that have so far dominated most previous explanations by economists of the S\&L crisis. ${ }^{9}$ In the first presentation of the model, the assumption that only legal transactions occur is also useful in bringing out the stark contrast between the theory of looting and the theory of go-for-broke. We subsequently show how the essence of the basic model carries over to a model in which owners may actually commit fraud.

Before presenting the three-period model, it is useful to make our basic point in the simplest possible setting and to establish some conventions that simplify our exposition. Let $V$ denote the true value or net worth of a limited liability corporation. Suppose that the government agrees to lend any amount of money to this corporation, subject to the restriction that the owners cannot pay themselves more than $M$. A single owner/manager then faces a very simple decision. If $M$ is less than $V$, the owner operates his corporation according to standard principles of value maximization. The government offer makes no difference to the owner. But if $M$ is greater than $V$, the owner borrows enough from the government to pay $M$, knowing full well that the corporation will default on this debt in the future. Worse still, in this case, the owner has no incentive to ensure that the corporation is well managed.

This, in essence, is our story of what happened at many thrifts. The details come in describing the regulations, accounting conventions, and opportunities for illegal payments that created situations in which $M$ exceeded $V$. Three aspects of this story deserve comment. In what fol-

9. See Craine (1992) for a recent description of a model with uncertainty that can capture the essence of the excessive risk-taking strategy. 
lows, we assume that there is no divergence of interests between managers and owners, unless we explicitly state otherwise. We do this partly to simplify the exposition, but also because it accurately characterizes the situation at many thrifts where the most important abuses took place. A crucial change in the regulations in the 1980 s made it possible for a single person to own a thrift or for a parent company to own a thrift as a subsidiary. As one would expect, abusive strategies are easier to implement when ownership is concentrated and managers are tightly controlled by owners. In fact, this is why bank regulators had enforced rules prohibiting concentrated ownership until the 1980s. There were other thrifts with widely dispersed ownership and serious divergences between the interests of managers (who wanted to keep their jobs and reputations) and owners (who would have made much more money if the managers had looted their institutions). They missed out on the action that we try to document.

A second part of this story-that the government is a direct lender to the firm-is a pure convenience. In practice, private individuals lend their deposits to a financial institution and the government guarantees the debts of the institution. For our purposes, this is equivalent to assuming that the depositor holds government debt and that the government lends money directly to the thrift. In either case, the result is the same when the thrift defaults. It is the government that suffers the loss.

The third part of this story-that wealth is shifted from the thrift to the private portfolio of the owner by means of dividend payments-is an expositional shortcut that should not be taken literally. In fact, there are many sweetheart deals whereby an individual or corporate owner of a thrift can extract resources from it. These other ways are typically illegal, but they can also be difficult to regulate and prosecute. Importantly from the point of view of the owners, they can substantially increase the total amount of wealth that can be extracted from a thrift. One example suggests the range of possibilities. In 1988, the Southmark Corporation exchanged a group of companies for some real estate holdings of San Jacinto Savings and Loan of Houston, Texas, a wholly owned subsidiary of Southmark. Because this was a transaction between affiliated companies, it required regulatory approval. Based on a fairness opinion provided by an investment banking firm that valued the contributed companies at $\$ 140.6$ million, regulators approved the trade for a compa- 
rable quantity of real estate from San Jacinto. By 1990, it had become clear that the value of the contributed corporations was actually negative. ${ }^{10}$

\section{The General Model}

We can now present the abstract model that forms the core of the analysis. It has no uncertainty and only three periods, dated zero, 1 , and 2 . The given market interest rate is $r_{1}$ between periods zero and 1 , and $r_{2}$ between periods 1 and 2 .

A thrift begins life in period zero with an investment by the owners of an amount $W_{0}$. The thrift acquires deposit liabilities $L_{0}$ and purchases a bundle of assets, $A$, whose initial value is $A_{0}=W_{0}+L_{0}$. The thrift is subject to a net worth or "capital" requirement imposed by the government. This specifies that the net worth $W_{0}$ must be greater than or equal to $c A_{0}$ for some constant $c$. The assets yield a cash payment of $\rho_{1}(A)$ dollars in period 1 and $\rho_{2}(A)$ dollars in period 2.

For simplicity, assume that the investment in the assets is not liquid and that the thrift does not purchase any new assets after period zero. In period 1 , the thrift receives cash payments $\rho_{1}(A)$ and pays a dividend $\Delta_{1}$ to its owners. To accommodate these transactions, the thrift adjusts its deposit liabilities. After these transactions, the deposit liabilities of the thrift will be the deposits from the previous period with accumulated interest, $\left(1+r_{1}\right) L_{0}$, minus the cash payment $\rho_{1}(A)$, plus dividends $\Delta_{1}$. This means that the thrift can borrow-that is, take in new deposits-to make the dividend payment $\Delta_{1}$.

In period 2, the investment in the asset makes its final payment and the thrift can be liquidated. The thrift receives payments $\rho_{2}(A)$. Deposit liabilities from period 1 with accumulated interest will be $\left(1+r_{2}\right)[(1+$ $\left.\left.r_{1}\right) L_{0}-\rho_{1}(A)+\Delta_{1}\right]$. The terminal net worth is the difference between the value of its assets and its liabilities.

If there were no limited liability and no deposit insurance, the decision problem facing the initial investors in the thrift would be to choose the bundle of assets $A$ to maximize the present discounted value of the payments from the thrift. (Because we shall later compare the present value of the optimal stream of earnings $V^{*}$ to the limit on dividend pay-

10. FDIC v. Milken (1991, pp. 76-77). 
ments, which is most naturally expressed in period-one units, it also makes sense to express $V^{*}$ as the period-one present value.) According to the preceding description of the earnings stream,

$$
\begin{gathered}
V^{*}=\max _{A, \Delta_{1}} \frac{\left\{\rho_{2}(A)-\left(1+r_{2}\right)\left[\left(1+r_{1}\right) L_{0}-\rho_{1}(A)+\Delta_{1}\right]\right\}}{1+r_{2}}+\Delta_{1} \\
\text { subject to } \quad 0 \leq c A_{0} \leq W_{0} .
\end{gathered}
$$

Because the two terms involving the dividend payment in period 1 cancel, the only important choice variable in this maximization problem is the assets purchased in period zero. Because the two terms involving dividends cancel, this equation can be simplified to yield

$$
\begin{gathered}
V^{*}=\max _{A}\left[\rho_{2}(A) /\left(1+r_{2}\right)\right]+\rho_{1}(A)-\left(1+r_{1}\right) L_{0} . \\
\text { subject to } \quad 0 \leq c A_{0} \leq W_{0} .
\end{gathered}
$$

Now suppose that this thrift is a limited liability corporation. Further suppose that the government guarantees the liabilities of the thrift and imposes an upper bound $M(A)$ on the amount of dividends that the thrift can pay to its owners in period 1. As the notation suggests, this upper bound could be a function of the assets that the thrift holds. In this case, the maximization problem facing the owners of the thrift becomes

$$
\begin{aligned}
& \qquad \begin{array}{l}
E=\max _{A, \Delta_{1}, \Delta_{2}}\left[\Delta_{2} /\left(1+r_{2}\right)\right]+\Delta_{1} \\
\text { subject to }
\end{array} \\
& 0 \leq c A_{0} \leq W_{0}, \\
& \Delta_{1} \leq M(A), \\
& \Delta_{2} \leq \max \left\{0, \rho_{2}(A)-\left(1+r_{2}\right)\left[\left(1+r_{1}\right) L_{0}-\rho_{1}(A)+\Delta_{1}\right]\right\} .
\end{aligned}
$$

In this expression, we introduce the new symbol $E$, the value of the owners' equity, because it can differ from the true economic value of the thrift, $V^{*}$.

To state the basic result of this section, we need one final definition. Let $M^{*}$ denote the maximum of $M(A)$ over all choices of $A$ satisfying $0 \leq c A_{0} \leq W_{0} . M^{*}$ is the maximum amount of dividends that can be extracted in period 1 . 


\section{PROPOSITION}

1. If $M^{*}$ is less than or equal to $V^{*}$-the period 1 maximum value of the thrift's flow of payments-the owners of the thrift choose $A$ to maximize the true value of the thrift.

2. If $M^{*}$ is greater than $V^{*}$, the owners of the thrift choose $A$ to maximize $M(A)$. They pay dividends in period 1 equal to $M^{*}$ and default on the obligations of the thrift in period 2.

PROOF

The economic intuition behind this result is very simple. If the owners cannot pay themselves more than the thrift is worth in period 1 , then the net worth of the firm is positive in the second period, and the choice of 0 in the maximum for second period dividends becomes irrelevant. In this case, the maximization problem in equation 3 with limited liability reduces to the maximization problem in equation 1 without limited liability that defines $V^{*}$.

If, on the other hand, the owners can pay themselves dividends greater than the true economic value of the thrift, they will do so, even if this requires that they invest in projects with negative net present value. By the adding up constraints, when they can take out more than the thrift is worth, they cause the thrift to default on its obligations in period 2. If they are going to default, the owners do not care if the investment project has a negative net present value because the government suffers all of the losses on the project. As a result, the owners choose $A$ solely with a view toward maximizing the amount of dividends that they can take out in period 1 .

(To derive this result formally, substitute the upper bound on dividends in period 2 into the maximand in equation 3 and reverse the order of the two maximization operators.)

Two observations follow immediately from this result. First, if the owners can extract more than the true economic value of the thrift, owners with a positive net worth will voluntarily choose to go bankrupt by extracting resources from it. Bankruptcy for them is a choice, not something that is forced on them by circumstances. Second, when owners choose $A$ to maximize $M^{*}$, they may invest in negative net present value projects. If so, the gain to the owners from the looting strategy is strictly less than the payouts by the government. As a result, society incurs a net loss. 
These observations illustrate most starkly the difference between the strategy we emphasize-bankruptcy for profit-and the more familiar strategies that depend on excessive risk-taking. According to our strategy, the preferred outcome for the owners of a solvent thrift is the one in which the thrift goes bankrupt. When the owners succeed in extracting more than the true economic value $V^{*}$, they will exhibit precisely the kind of indifference to how the thrift is managed that one sees when one examines the daily operations of many bankrupt thrifts. According to the alternative strategy of excessive risk-taking, the preferred outcome for the owners is the one in which the gamble pays off and the thrift remains solvent. If owners were following this strategy, they would be concerned about the quality of their loans and the size of the operating expenses that they incur, because every dollar of loan loss or expense represents a subtraction from their gains if the gamble pays off.

These results also justify our use of the term looting. The bankruptcy for profit strategy can induce large losses to society as a whole because the dependence of $M$ on $A$ can encourage thrift owners to invest in negative net present value projects. The next section shows how these kinds of incentives were created by the regulations in place during the $1980 \mathrm{~s}$.

The model so far has assumed that $M(A)$, the limit on payments in period 1 , is given only by regulatory and accounting rules, so that all choices made by the thrifts are legal. Our examples of looting, however, preponderantly involve illegal activities. In part, the high proportion of illegal activities relative to legal ones in our examples reflects a bias in our sources, which are mainly derived from evidence in legal proceedings. The looting that was legal or impossible to prosecute never surfaced in court or regulatory proceedings. But, in fact, we believe that the opportunities for legal looting were relatively small relative to the opportunities that include a large variety of ingenious side payments, with varying chances of detection, criminal prosecution, and civil recovery. The model should therefore be extended to include both illegal and legal means of looting.

To do this, let $F$ denote the fraudulent activities undertaken by managers. We make two assumptions about $F$. First, an increase in $F$ leads to an increase in the expected cost $C(F)$ associated with the risk of being prosecuted or sued by the authorities. These expected costs will depend on the probabilities of losing in court and the cost of losing in a criminal or civil case. They will also depend on the attitudes toward risk of the 
managers and owners, as well as the reputation costs associated with legal action.

The second effect of an increase in $F$ is an increase in the amount of total resources that could be extracted by owners. Typically, these resources would not take the form of explicit dividend payments, but they still represent reductions in the net worth of the institutions. From the point of view of the true position of the balance sheet of the thrift, they have the same effect as dividend payments. Thus, we can expand our previous expression for the limits on extracted wealth in the first period $M(A)$ and write $M(A, F)$, with the understanding that $M$ is increasing in $F$.

With these extensions, our model can now be written as follows:

$$
\begin{aligned}
& E=\max _{A, F, \Delta_{1}, \Delta_{2}} \Delta_{2} /\left(1+r_{2}\right)+\Delta_{1}-C(F) \\
& \text { subject to } \\
& 0 \leq c A_{0} \leq W_{0}, \\
& \Delta_{1} \leq M(A, F), \\
& \Delta_{2} \leq \max \left\{0, \rho_{2}(A)-\left(1+r_{2}\right)\left[\left(1+r_{1}\right) L_{0}-\rho_{1}(A)+\Delta_{1}\right]\right\} .
\end{aligned}
$$

The basic intuition from the previous model carries over into this extended model. A critical value separates the economics of value maximization from the economics of bankruptcy for profit. As above, let $V^{*}$ denote the maximized value of dividends when there is no scope for looting. In this case, let $M^{*}$ denote the value of the maximum of $M(A, F)-$ $C(F)$ over $A$ and $F$. This quantity is the total monetary value that can be extracted from the thrift minus the expected legal cost associated with the chosen level of fraud. If $M^{*}$ is greater than $V^{*}$, owners will loot; that is, they choose $A$ and $F$ to maximize $M(A, F)-C(F)$. If , on the other hand, $M^{*}$ is less than $V^{*}$, they set $F$ equal to zero, choose $A$ to maximize value, and collect $V^{*}$.

In summary, when $V^{*}$ is small, or when the amount that can be extracted from firms with little chance of prosecution is large, looting and illegality are likely to occur. Regulation, proper accounting, and effective enforcement of the law are necessary to ensure that $V^{*}$ exceeds $M^{*}$. There must be limits on legal payments consistent with true economic returns. In addition, accounting and regulatory definitions must make illegal payments easy to detect, prosecute, and recover. 


\section{Examples of Looting}

For financial institutions, one rule that limits dividend and other kinds of payouts from a thrift is derived from the requirement that in every period, the net worth of the thrift must exceed the capital specified by regulators. In our three-period example, the dividend limit, $M$, in period 1 is determined by the requirement that after dividends have been paid, the remaining net worth of the thrift must exceed the constant $c$ times the book value of the asset. Thus in the model where thrifts are operating legally, $M(A)$ can be derived exactly from regulatory constraints and accounting definitions.

\section{Example 1: Inflated Net Worth}

We begin with a point about accounting rules that is so obvious that it would not be worth stating had it not been so widely neglected in discussions of the crisis in the savings and loan industry. If net worth is inflated by an artificial accounting entry for goodwill, incentives for looting will be created. Because net worth imposes the critical limit on the ability to extract value from a thrift, each additional dollar of artificial net worth translates into an additional dollar of net worth that can be extracted from the thrift. In particular, if the artificial increase in net worth is bigger than the total required capital, the conditions for looting will be satisfied. This possibility was enhanced because the capital requirement, $c$, was substantially reduced during the $1980 \mathrm{~s}$.

During the 1980s, an artificial increment to regulatory net worth could arise for several different reasons. In circumstances in which one thrift purchased another thrift with a negative net worth, "goodwill" was created that had exactly the effect of the increment described here. Alternatively, many thrifts were allowed to continue in operation after their true net worth was substantially negative. According to regulatory accounting principles, an artificial increment to net worth was created to remove the legal obligation that regulators would otherwise have had to close such a thrift. (We discuss both goodwill accounting and capital requirements below.)

Overstated net worth by itself does not induce the owners of a thrift to make bad investment decisions, but bankruptcy for profit removes any 
incentive to manage a thrift carefully. As a result, net losses to society from mismanagement of the thrift are likely.

\section{Example 2: Riding the Yield Curve}

Suppose that a thrift is allowed no goodwill in calculating its net worth, but is given the opportunity to invest in assets that generate exaggerated first-period accounting income. Then the thrift will once again be able to pursue bankruptcy for profit.

To use a simple example, consider long bonds. Because there is no uncertainty in the model, arbitrage implies that a two-period long bond issued at par in period zero would have to pay a coupon, $r_{L}$, satisfying

$$
\left(1+r_{L}\right)+\left(1+r_{2}\right) r_{L}=\left(1+r_{1}\right)\left(1+r_{2}\right) .
$$

Neglecting the cross terms $r_{2} r_{L}$ and $r_{1} r_{2}$ gives the usual approximation from a pure expectations theory of the yield curve, $r_{L}=\left(r_{1}+r_{2}\right) / 2$. We will be interested in the case where spot rates are increasing over time, so assume that $r_{2}>r_{L}>r_{1}$.

According to accounting conventions that are still used for a bank or thrift that plans to hold long bonds to maturity, a long bond held in the investment portfolio of a thrift would be valued at par in period 1 , even though the market value of the bond would be strictly less than par because interest rates are rising over time. (All that is required for this accounting treatment is an intention by the thrift to hold the bond to maturity.) According to this convention, the accounting return on the investment in the bond is its coupon $r_{L}$, which by our assumptions is strictly greater than the true economic return $r_{1}$. If the difference is large enough to satisfy

$$
r_{L}-r_{1}-c \geq 0,
$$

the conditions required to pursue bankruptcy for profit will be satisfied. For many thrifts, the effective value of $c$ could be very small, so that only a small differential between the accounting rate of return $r_{L}$ and the true economic rate of return $r_{1}$ on assets would be needed to make bankruptcy for profit attractive.

Under these circumstances, all a thrift would need to do to exploit bankruptcy for profit is to raise its funds at the prevailing short rate (for example, in the market for certificates of deposit), invest in higher-yielding long bonds, and pay out all of its accounting earnings $\left(r_{L}-r_{1}\right) A$ 
as dividends. If $r_{L}-r_{1}$ is equal to $c$, then in the first period, the owners will be able to use artificial profits to extract their initial investment, $W_{0}=c A$, without violating the net worth requirements specified by the regulations. If $r_{L}-r_{1}$ is greater than $c$ (or if the yield differential persists for several periods in a multiperiod model), the owners can take out more than the value of their initial investment.

When period 2 arrives, the thrift will be obligated to pay a rate of return on its deposits that exceeds the yield on its bonds. If the owners have been able to extract more than the current value of their initial investment, then the thrift will not be able to make good on this commitment and the government will have to take over its obligations.

Note that in contrast to the first example, the rule determining dividend payouts in this example does give thrifts an incentive to purchase a particular kind of asset, but it is not one with a negative net present value. Hence, as in the first example, the accounting rules do not give owners a direct incentive to make a negative net present value investment. As in all cases of bankruptcy for profit, however, the owners have no stake in future gains and losses at a thrift, and therefore will be indifferent to actions that cause social losses.

It is tempting to conclude that this example represents an instance in which a thrift takes a gamble and exposes itself to interest rate risk, but this interpretation is misleading. In this perfect certainty model, there is no risk. The outcome here is perfectly foreseeable. Moreover, as noted above, the outcome that is preferred for the owners is the one in which the thrift is left insolvent, not the one in which it has a positive net worth.

The strategy of riding an upward-sloping yield curve that is illustrated here is not one that was particularly important during the 1980s, but it does illustrate the essence of the point that we are trying to make. If regulations make use of accounting values that differ from true economic or market values, this creates opportunities for abusive behavior that can be consistent with the letter of the law.

Preventing this kind of abuse is also very simple. If all long bonds are marked to market in period 1 , no artificial accounting earnings are generated. It is a revealing fact about the regulatory process and about the accounting profession that historical prices may still be used to value government securities that are to be held to maturity. ${ }^{11}$

11. See Floyd Norris, "Bond-Accounting Shift Is Approved," New York Times, April 14, 1993, p. C1. 


\section{Example 3: Acquisition, Development, and Construction Loans}

For a thrift that is interested in bending accounting rules and overstating net worth, acquisition, development, and construction (ADC) loans are an example of a thrift asset that offered particularly rich opportunities for booking artificial accounting earnings. Real estate investments also created opportunities for owners to make side payments to themselves in a way that was difficult for regulators to monitor and for law authorities to prosecute successfully.

In the most extreme cases, an ADC loan took the following form. A thrift would make a no-recourse loan to a land developer, offering enough money to purchase a tract of land, construct a building, pay the developer a development fee, pay the thrift an initial origination fee on the loan (typically about 2.5 percent of the loan amount), and pay the interest on the loan for the first several years of the project. The thrift could inflate its accounting income for several years by finding an unscrupulous individual with little development experience, and making the following offer. Without putting any money into the project, the developer could borrow money and collect development fees and salary income for several years. In return, the developer would agree to "pay" the thrift some of its own money in what appeared to be payments on a loan with a very high interest rate. Because the developer would have little or no experience in development, the project would have a negative net present value. This fact alone would be sufficient to ensure an eventual default on the loan by the developer in most cases. The unrealistically high interest rate on the loan would virtually guarantee a default. Because the loan would be a no-recourse loan, the developer could walk away from the project keeping his fees, without putting his personal wealth at stake.

Neglecting for simplicity the origination fees (which technically would generate income in period zero), we can treat this loan as an asset that pays a very high accounting return in period 1 equal to the interest rate on the loan. As in the last example, all that is required for looting to be profitable is that the analog of the inequality in equation 6 be satisfied. The excess accounting profit that the thrift can earn over its cost of funds need only be large enough to exceed the capital requirement, $c$, which, as we have already noted, could have been quite small. 
In contrast to riding the yield curve, this arrangement is very difficult to police because real estate projects that are under construction are inherently difficult to value. Because reserves are created to make the initial interest payments when the loan was taken out, the loan cannot go into default in period 1 . If a suspicious regulator or accountant challenges the value of the collateral backing up the loan, the thrift owner can arrange for a cooperating appraiser to certify that the value of the project is sufficient to protect against loss on the loan. If necessary, the thrift (or a cooperating thrift) can make a loan to a new developer to purchase the project from the first developer at a profit, "proving" with a market price the appraisal's validity. In period 2, the developer defaults, the "highly profitable" thrift suddenly is insolvent, and the government must provide funds to pay off the depositors.

We want to emphasize that an honest developer would not enter into this kind of agreement with the thrift. Even if the developer cannot be held personally responsible for the loan once the project defaults, a default on a major project would damage the reputation of a reputable developer and limit the ability to borrow in the future, especially once the abusive nature of the arrangements becomes clear. As a result, the owners of the thrift have an incentive to seek out the most unscrupulous "developers," the ones that it can count on to report grossly overstated interest payments in early years and then to default in subsequent years. Because high dividend payments are likely to attract regulators' attention, other means of extracting money from the thrift are in most cases more profitable, such as no-recourse financing for an overvalued purchase of land from the owners or participation in other sweetheart deals. All of these activities entail some risk of prosecution if they are done flagrantly, but if they are undertaken with care, they are very difficult to prosecute. The perverse incentives created for the owners of the thrift will propagate through the economy, creating misleading price signals and perverse incentives in other parts of the economy. The owners of the thrift pursue bankruptcy for profit, but now, so do the symbiotic developers that it attracts.

In this case, it is clear that bankruptcy for profit fully lives up to our definition of looting. The development projects that are undertaken in this kind of arrangement would typically have a net present value that was substantially negative. In Texas, some of the completed projects 
that went into default were of such poor quality that the buildings that had been built were simply bulldozed.

\section{The Financial Crisis in Chile}

In the previous example of riding the yield curve, the depository institution holds assets that pay a high current yield. Its liabilities, by contrast, have a low current yield. The yield spread results in high current accounting income that can be paid out to shareholders. This current accounting income is, however, not the true economic return on the portfolio, because part of that high current yield merely offsets an expected depreciation in the capital value of the long-lived assets. The anticipated fall in asset values is associated with an expected increase in short-term interest rates.

In this section, we describe a related case, one in which the anticipated decrease in asset values comes from an expected depreciation in exchange rates. In this case, the artificial accounting income can be generated by a mismatch between the currencies in which assets and liabilities are denominated instead of a mismatch in the duration of the assets and liabilities.

To show how a bank can exploit an expected depreciation of the currency under a fixed exchange rate system, suppose that the following four conditions hold. First, the assets of the bank are denominated in the home currency (which we will call pesos). Second, the liabilities of the bank are denominated in the foreign currency (which we will call dollars). Third, there is an expected devaluation of the peso relative to the dollar (that is, an expected fall in the number of dollars offered in exchange for one peso) that is mirrored in a nominal interest rate on peso loans that exceeds the nominal interest rate on dollar loans. Fourth, dollar lenders charge a bankruptcy premium on their loans to the bank that is less than actuarially fair because they have confidence that the pesoissuing government will assume responsibility for the dollar-denominated borrowing by its banks.

Under these conditions, the bank can consider the difference between interest payments in pesos and interest payments in dollars as current profit, and these can be paid out as bank earnings. Of course, this profit is illusory, because the high rate on pesos relative to dollars 
reflects the expected devaluation. A correct system of accounting would set aside all of the extra earnings from the interest rate premium as a reserve against future losses in asset values arising from changes in the exchange rate. But if the official policy is that no change in the exchange rate will occur, it is difficult for government regulators to insist that firms accrue this kind of reserve.

The preceding outline suggests how fixed exchange rates and misleading accounting can encourage a pattern of bankruptcy for profit that ultimately results in an economy-wide financial crisis. No actual financial crisis will ever be quite this simple because bank regulators will try to stop the bankruptcy for profit scheme that we have just described; furthermore, illegal, as well as legal, means will be used to extract payments. It is therefore useful to review at least one actual devaluation to see whether it is the regulators or the looters who come out ahead. Because there are several excellent accounts of the Chilean financial crisis of 1982 that leave relatively little ambiguity about the facts, we focus on this case. ${ }^{12}$

In 1979, the reformers of the Chilean economy had achieved considerable success. Inflation in the consumer price index (CPI) had fallen to 38 percent per year, from an annual peak of more than 600 percent in 1973. Real gross domestic product had grown by 30 percent over the four-year period from 1975 to $1979 .{ }^{13}$ Structural changes involving reduced protection of domestic industry had resulted in a rapid expansion of the manufacturing sector.

Emboldened by these successes, the economic ministers decided to go one step further. They would end inflation by slowing the rate of devaluation of the currency and then fixing the peso-dollar exchange rate. In June 1979, this permanent rate was established at 39 pesos to the dollar. ${ }^{14}$ Over the next nine months, restrictions on capital inflows and outflows were greatly relaxed, including restrictions on banks' foreign liabilities. But for reasons mainly outside the operation of the financial sector, the pegging of the exchange rate proved to be unrealistic. Inflation had a momentum of its own and could not be halted immediately. In particular, union wages were fully indexed to past inflation. Thus even if

12. See Edwards and Edwards (1991), de la Cuadra and Valdes (1992), McKinnon (1991), and Velasco (1991).

13. Edwards and Edwards (1991, table 2-1, p. 28, and table 1-3, p. 12).

14. Edwards and Edwards (1991, p. 38). 
inflation had abruptly stopped (as the planners had hoped), wages would have still risen substantially because of past increases in the CPI. In fact, both wages and the general price level continued to rise even after the exchange rate was pegged. Inflation did indeed decelerate, but from the third quarter of 1979 to the last quarter of 1981, the real exchange rate (in pesos per dollar, adjusted for inflation in each country) appreciated by 50 percent. Blue collar real wages grew by 20 percent from May 1979 to May 1981. For 1981 as a whole, the CPI inflation rate was 9.9 percent. ${ }^{15}$

The peso exchange rate thus became steadily more and more overvalued, and as time passed, there were growing reasons to expect the official policy of a fixed exchange rate to collapse with a devaluation of the peso. There were virtually no restrictions on the flows of capital, so the peso interest rate should have rapidly approached something close to the rate implied by uncovered interest parity-the dollar rate plus the expected rate of depreciation. In the absence of any further regulations on bank behavior, the banks could have borrowed dollars and loaned in pesos, as described above, with the difference between the interest received and the interest paid considered as current income.

Bank regulators were aware of exchange rate risk and required that banks match their dollar assets with their dollar liabilities. ${ }^{16}$ Banks responded, in effect, by converting exchange rate risk into credit risk that regulators could not monitor. To see how this is possible, consider a simple example. Suppose that a bank borrows from a major international bank at the London Interbank Offered Rate (LIBOR). The international bank is willing to lend to the Chilean bank without charging a default premium because it is sure that the Chilean government would assume the debts of the bank if it were to fail. Suppose that a firm borrows dollars from the bank and invests the proceeds in peso-denominated financial assets. This firm is now in a position to engage in looting based on the mismatch between the currencies in which its assets and liabilities are denominated. It enjoys a large spread between its current income and its cost of borrowing; it can therefore report substantial current earnings and pay these out as dividends, with the expectation that it will default on its dollar loans when the peso finally depreciates.

15. Edwards and Edwards (1991, table 3-9, p. 75; table 6-7, p. 158; and table 2-1, p. 28).

16. de la Cuadra and Valdes (1992, pp. 76-77). 
Of course, any bank that is trying to maximize economic value will not lend to the firm on terms that would make looting possible; but the bank in our example is willing to do so because it too has an incentive to loot. As in the case of a thrift engaged in ADC lending with a cooperating developer, the bank and the borrower have the same incentive to pursue bankruptcy for profit. To make the example concrete, let us apply our example to the interest rates prevailing from 1979 to 1981, during the period when exchange rates were fixed in Chile. The annual rate on peso loans from Chilean banks was around 50 percent, the rate on dollar loans about 20 percent, and the LIBOR rate roughly 15 percent. ${ }^{17}$ Given these rates, the bank in our example can lend dollars to the firm at a 20 percent annual interest rate, knowing full well that the firm will default on its loans when the currency is realigned. The bank now has dollar liabilities on its books on which it pays 15 percent interest and matching dollar assets (as required by the regulations) on which it collects 20 percent interest. (Banks were presumably limited in their ability to charge higher rates because an implausibly large spread over LIBOR would have been a clear signal that something other than a standard arms-length transaction was taking place.) Until the depreciation takes place, the bank can report strong profits and pay large dividends. At the same time, the firm can report as income the spread between its 20 percent cost of funds on dollar loans and its 50 percent return on its peso loans.

As the yield-curve and ADC examples given above show, this strategy requires that both the bank and the firm be able to report and pay out artificial earnings that are greater than the total equity that the owners have in each corporation. The inequality in equation 6 shows that this will be possible if the yield differential times the holding period (which in this case is the expected time until the depreciation) is greater than the ratio of net worth to total assets. It does not take a big spread between the dollar and peso interest rates for a bank to be able to meet this condition because net worth-to-asset ratios for banks are so small. It was not the case, however, that economic conditions forced all banks into bankruptcy. The conservatively managed Banco del Estado de Chile and the local affiliates of foreign banks did not follow a strategy of bankruptcy for profit and did not become insolvent when the devaluation took place. If a firm has substantial equity, and regulators can monitor and limit 
the debt-to-equity ratio for the borrowers from banks, it can take a large interest rate spread to make looting profitable. But for firms that are already on the verge of bankruptcy, it takes virtually no spread at all. In Chile in 1981, there were many such firms. Faced with an appreciating exchange rate, very large rises in real wages, and double-digit real interest rates (that is, peso interest rates minus the peso CPI inflation rate), many Chilean entrepreneurs had little remaining capital in their enterprises. Any such enterprise that could remain alive in the absence of the peso depreciation, but that would fail when the peso depreciated, would have been willing to pay a premium above the dollar rate of interest for a dollar loan. These firms would have preferred dollar loans to peso loans, as long as the dollar rate of interest did not exceed the peso rate of interest. As a result, the banks had a source of demand for dollar loans that induced them to borrow abroad from New York banks, who were anxious to lend to them at little more than the dollar interest rate. Thus, for example, the construction industry increased its dollar-denominated debt by 284 percent in 1981 alone. ${ }^{18}$ The increased demand for dollar loans by Chilean banks is shown by a ten-fold increase in their foreign indebtedness from 1978 to 1982 , accounting for 70 percent of the total increase in Chilean private indebtedness over this period. ${ }^{19}$

As described, this arrangement gives the bulk of the profits from looting to the firms that can exploit the yield spread. Judging only from the interest rate data, banks apparently were able to capture relatively little of the loot. This conclusion, however, is based on the mistaken assumption that the banks were not related to the borrowers. In fact, most large Chilean banks were part of a business grupo (or interlocking group of firms like a Japanese keiretsu). By having a bank in the group lend to a firm in the same grupo and then having the firm lend at the peso rate, the owners could capture the entire spread of 35 percentage points between LIBOR and the domestic peso rate. Retrospective analyses have attached great importance to the role of the banks in such self-dealing between the banks and the firms in the corresponding group. ${ }^{20}$ According to James Tybout, grupo firms borrowed from their affiliated banks at preferential rates, and purchased equity in affiliated companies

18. See de la Cuadra and Valdes (1992, p. 86).

19. See Edwards and Edwards (1991, table 3-8, p. 71).

20. See Edwards and Edwards (1991, pp. 100-01) and the discussion by McKinnon (1991, p. 40). 
to boost share prices, thus transferring gains to their owners through share price appreciation rather than through direct dividend payments. ${ }^{21}$ In addition, loans by banks to grupo firms were one of the two largest uses of foreign dollar borrowings, matched only by trade financing.

\section{The Looting of Savings and Loans during the 1980s}

This section relates the abstract discussion of looting to the facts concerning the savings and loan crisis in the United States. We make three basic points. First, changes in regulations and accounting conventions encouraged the strategies for looting described in the theoretical section. They also increased the amount of wealth that could be extracted by someone who was willing to incur any given level of risk of prosecution. We document the most important changes in regulation and connect them to the models. Second, we examine detailed accounts of the savings and loan crisis for indications that looting did indeed take place. We find abundant evidence of investments designed to yield artificially high accounting profits and strategies designed to pay large sums to officers and shareholders. Third, by adding up the available accounts of looting, it becomes clear that looting could have been a significant contributor to the $\mathrm{S} \& \mathrm{~L}$ crisis.

\section{Changes in Regulations}

At the beginning of the 1980s, the U.S. savings and loan industry was in deep trouble. As has been widely noted, regulations had induced S\&Ls to hold a mismatched portfolio of assets and liabilities that exposed them to significant interest rate risk. By 1980, many honestly run S\&Ls had a negative net worth. The industry as a whole was under water by more than $\$ 100$ billion. ${ }^{22}$ The deposit insurance fund did not have enough assets to cover its liabilities.

The federal government had the choice of letting the insurance fund fail, making up the difference with tax revenue, or changing the rules. Letting depositors lose their deposits was unthinkable. Explicitly bailing out the insurance fund was inconvenient. So the rules were changed.

21. Tybout (1986, p. 378).

22. See Kane (1989, p. 75) and White (1991, p. 77). 
These rules were changed in two principal ways: first, by amending the accounting definition of current income; and second, by changing the definition of net worth or capitalization. These changes were enshrined in the RAP (Regulatory Accounting Procedures), which replaced the GAAP (Generally Accepted Accounting Procedures) as the accounting standards required by regulators. Furthermore, the official policy became one of "forbearance."

At the same time, thrifts suddenly found themselves freer to choose their investment activities and set deposit interest rates as they wished. First, the Depository Institutions Deregulation and Monetary Decontrol Act of 1980 and the Garn-St. Germain Depository Institutions Act of 1982 removed many of the restrictions that had previously applied to asset-holdings by thrifts. As thrifts switched from state to federal charters to take advantage of the new opportunities, some states (Texas and California, for example) reacted by adopting even more liberal rules. Second, by eliminating limits on the rates that could be paid on deposits, Garn-St. Germain not only removed the last vestige of franchise value that had helped deter looting in the past, but it also, in effect, gave thrifts an unlimited ability to borrow from the government. To place a new claim on the deposit insurance system, which was implicitly backed by the government, thrifts had only to take in new deposits. Previously, they had been limited to geographically restricted, nonprice competition as a means of attracting deposits. With the removal of interest rate limits, the only constraint on the behavior of thrifts was the severely weakened system of capitalization or net worth requirements. The emergence of a nationwide system of brokers who matched depositors with thrifts was an inevitable response to this change.

The ability to purchase a more diverse set of assets made the valuation of the portfolio held by a thrift more difficult and created opportunities for overvaluation of net worth that could be manipulated by individual thrifts. Increases in the amount that a thrift could lend to one borrower also enhanced the ability of thrift owners and borrowers to collude by funding and carrying out negative net worth projects that generated extractable gains. Traditionally, thrift ownership had to be dispersed among at least 400 shareholders, with no individual shareholder holding more than 10 percent of the equity, and no group holding more than 25 percent. An additional rule change made it possible for a single 
individual to own his or her own thrift, making it even easier for owners to structure the affairs of the thrift for private benefit. ${ }^{23}$

The strategy of forbearance in dealing with thrifts that could not meet their capital requirements was supplemented by a significant weakening of the capital requirements themselves. At the beginning of the 1980s, capital requirements specified that the book value of equity had to be 5 percent of the book value of an institution's assets. By January 1982, the capital requirement had been reduced to 3 percent. ${ }^{24}$ Moreover, new thrifts were given 20 years to reach the required capital levels, so an entrant into the industry needed to maintain only net worth equal to 0.15 percent of assets. ${ }^{25}$ Rapidly growing thrifts were also allowed to use an average of assets of the previous four years' and the current year's (much larger) assets. ${ }^{26}$ Thrift owners, who were often land developers, could also deed land or other assets that were difficult to value to their thrift as a contribution to capital.

The new RAP rules, together with generous interpretations of the traditional GAAP rules, created many different ways in which net worth could be overstated. Institutions with significantly negative net worth could then remain open, report profits, and, in most cases, make payouts to managers and owners. S\&Ls could value at current market prices some assets that increased in value, yet retain losers on the books at historical cost. Losses on assets that were sold could also be amortized over the maturity of the assets rather than incurred instantaneously, as they should be under any economically rational system of accounting. ${ }^{27}$

Regulators were not, of course, completely blind to the potential problems that their strategy created. For example, when the Federal Home Loan Bank Board, the regulatory agency of the S\&Ls, first began to issue "net worth certificates"- pieces of paper that were treated as increments to the net worth of an insolvent institution-it insisted that the recipients cease dividend payments until the certificates were no longer needed. However, once the pattern of forbearance and stretching
23. See Mayer (1990, p. 63).
24. See Breeden (1990, p. 8).
25. See Breeden (1990, p. 8).
26. See Breeden (1990, pp. 8-9).
27. Breeden (1990, p. 16). 
of the accounting rules became the norm, the regulators' ability to limit opportunism rapidly diminished.

A particularly important accounting provision concerned the treatment of the intangible assets or "goodwill" created when one thrift acquired another. Traditional GAAP accounting rules specified that when an acquiring firm paid more for a target than its book value, the difference was identified as an intangible asset that was added to the books of the acquiring firm and depreciated over an appropriate period of time. In the world of value maximization, this is sensible. If someone is willing to pay more than book value, the firm must possess some hidden assets. But in the world of bankruptcy for profit, this procedure can lead to seriously misleading accounting procedures. Traditionally, the Federal Home Loan Bank Board instructed thrifts to limit this period to no more than ten years, but in 1981, this restriction was removed and thrifts could use the absolute upper bound of forty years under GAAP rules. ${ }^{28}$

To illustrate the effects of this decision, consider the following example. Suppose that a troubled thrift had mortgages with a face value of $\$ 4$ billion but a market value of $\$ 3$ billion because interest rates had increased. Suppose that it had deposit liabilities of $\$ 3.8$ billion, and therefore a negative net worth of $\$ 800$ million. If another thrift acquired this thrift at zero cost by taking over its assets and liabilities, it put $\$ 3.8$ billion in new deposit liabilities on its books. Because the transaction had a market price of zero, it also put the $\$ 3$ billion in new mortgage assets on its books, together with $\$ 800$ million of intangible "goodwill" assets. From the point of view of the regulators, this paper transaction meant that the measured capital of the industry had increased by $\$ 800$ million and that an insolvent institution had been resolved. Income at the acquiring thrift would be directly reduced, because the market value of the target was negative. With interest rates of 10 percent, the net reduction in income would be 10 percent of the difference between $\$ 3.8$ billion and $\$ 3$ billion, or $\$ 80$ million per year.

In the usual world of value maximization, of course, it never makes sense for an acquiring firm to accept $\$ 800$ million in net new obligations for free. But in the world of bankruptcy for profit, this extravagance made perfect sense because it allowed the acquiring firm to pay out more dividends than would otherwise have been possible. Over time, both the

28. Black (1990, p. 104) and Breeden (1990, pp. 21-25). 
goodwill and the discount from par on the mortgage assets disappear, but the accounting treatment lets this happen at different rates. If the average life of the outstanding mortgages were seven years (a typical value because mortgages are repaid when a house is sold), the acquiring thrift would be allowed to book one-seventh of the discount from par as income each year. In this case, it would generate $\$ 143$ million ( $\$ 1$ billion/7) in additional accounting income each year. Because the goodwill would be depreciated over forty years, the subtraction from accounting income in each year would be only $\$ 20$ million. Over the course of the first seven years after the acquisition, this difference would generate $\$ 123$ million per year in artificial income. Net of the real reduction of $\$ 80$ million per year, this would imply an additional $\$ 43$ million in dividends that could be paid out each year for the next seven years. After seven years, the discount from face value would be gone and even accounting earnings would be strictly lower. But in seven years, the current owners would presumably be long gone. Many thrift owners were quick to take advantage of this loophole: in 1982 alone, S\&Ls booked $\$ 15$ billion in goodwill. ${ }^{29}$

Another particularly important accounting provision was the new leniency concerning S\&L income from ADC loans to real estate developers. The Garn-St.Germain Act removed the traditional limits on the mortgage loan-to-value ratio, ${ }^{30}$ and-even better, from the looters' perspective-allowed the value of the project itself to include interest reserves to pay the interest on the loan for the first several years, as well as a 2 to 4 percent developer's fee that could be taken out at the beginning. This meant that a developer could start a real estate development project with no equity of his own at stake, and pocket a large initial fee. Thanks to the interest reserves, both the developer and the thrift could operate free of any fear of default for years, even if the project being built were completely worthless. ${ }^{31}$ The new Regulatory Accounting Procedures also allowed the $\mathrm{S} \& \mathrm{Ls}$ to book as current income an origination fee of up to 2.5 percent of the loan value. ${ }^{32}$ While correct accounting would have required loan-loss reserves to be set aside against the risks of loss, practice frequently differed. In Texas, for example, accounting

29. Breeden (1990, p. 24).

30. See Kane (1989).

31. O'Shea (1991, p. 55).

32. See Breeden (1990, p. 19). 
practices allowed both the nominal interest income and the origination fee to be booked as profit-even if the developer never contributed a single dollar of his own wealth to the project.

These accounting arrangements created the perfect opportunity for developers and thrifts to collude in looting by creating overvalued assets, as described earlier. Developers created projects that were initially given artificially inflated accounting valuations and subsequently went bankrupt, with thrifts lending all the funds needed to keep the project in business for several years. This scam ultimately became known as the "Texas strategy" for looting. The effects of this strategy on the real estate market are the subject of the next section.

Among the many provisions reducing the restrictions on asset holdings, the Garn-St. Germain Act of 1982 also allowed thrifts to engage in commercial lending and therefore to purchase junk bonds. Junk bonds offered the same kind of yield spread described in the yield curve example and exploited in Chile. Correct accounting would have required a reserve to offset the high default rate on junk bonds, ${ }^{33}$ but lacking adequate supervision requiring risk set-asides, thrifts could report virtually all of the interest income on junk bonds as current income. The implications of this arrangement for the market for junk bonds are discussed later in the paper.

\section{Evidence of Looting}

We have seen that the changes in regulations of S\&Ls in the early 1980 s created opportunities for looting. But did many owners in fact loot their institutions? If they did, did they mainly purchase high-risk assets in the hope that they would sometimes create large positive earnings for their institutions? Or were looting strategies that drained as much income as possible also an important factor in the ultimate cost of the S\&L bailout?

Evidence of looting abounds. This evidence is mainly microeconomic rather than macroeconomic in nature, because both looting and highrisk strategies could be used to milk the S\&Ls and leave many institutions in deep bankruptcy. To establish a case for looting, it is necessary to show that loans were made, or assets purchased, in circumstances in

33. That rate was one-third after eleven or twelve years, according to Asquith, Mullins, and Wolff (1989, p. 929). 
which no reasonable person could expect a future positive payoff in any future state of the world, but for which the present payoff was very high. An example of this kind would be the loans made by Oakland-based FCA, a rapidly growing thrift that grew to $\$ 34$ billion in assets before it failed. ${ }^{34}$ According to one account, FCA followed a strategy of extremely rapid growth during which it was willing to make loans to any developer willing to pay 20 percent interest plus points, a policy which in the S\&L industry was known to attract "lemons," projects headed for almost certain default. ${ }^{35}$ According to another account, FCA would buy whatever mortgage brokers in the Southwest wanted to sell, and then would unload these mortgages to third parties, lending them the money to buy the mortgages but not forcing the borrowers to keep to their repayment schedules. ${ }^{36}$ These policies clearly correspond more closely to a bankruptcy-for-profit strategy than gambling for resurrection as it is difficult to imagine any state of the world in which bankruptcy could have been avoided.

The Texas strategy, first apparent in the examination of Mesquite, Texas-based Empire Savings and Loan, suggests just as strongly that negative yield, rather than high variance, was the dominant characteristic of the asset portfolios of many thrifts that later failed. This strategy was followed in many different forms by different S\&Ls. The first step was to make a loan-often to a developer-for more than the value of the collateral. Various complex systems could be worked out for overvaluing the collateral. In the case of Empire Savings and Loan, for example, a group of colluding developers and thrift owners traded land back and forth in a series of trades at successively higher prices; because their parcels were sufficiently similar, these trades could be used for price evaluations by a friendly appraiser.

Once the development loan was granted, the development itself, as in our model, became a source of generous development fees. The developer would pay a high current return on the loan, often made easier because the loan included payments of interest for the understandably long time until the completion of the project. As a result, the S\&L would receive high current payments for some period of time. Furthermore, the

34. Stein (1992, p. 206).

35. See Robinson (1990, pp. 26-27). This adverse selection problem corresponds to the reason for rationing of loans given by Stiglitz and Weiss (1981).

36. Mayer (1990, p. 111) 
developer, whose talents at building had been appreciated and supported by the $S \& L$, might in turn see what a promising future the $S \& L$ would have, with its high current earnings and massive growth rate. So the developer and his friends could purchase a sizable bloc of stock in the S\&L by contributing overvalued land or projects that could be counted as part of the thrift's capital. The only effective limit on the returns from this strategy was the thrift's ability to find new individuals with reasonably clean criminal records and balance sheets who were willing to play the role of developer, because regulations still put a limit on how much a thrift could lend to any one person or firm. Empire eventually offered finder's fees to anyone who brought in a new potential "developer." All that was required was a financial statement that was clean enough to pass muster with the bank examiners. ${ }^{37}$

Table 1 contains a list of thrifts for which government investigators considered evidence of fraud to be the strongest. Adding up the resolution costs for those for which we could find cost estimates generates a total cost to the government of $\$ 54$ billion. This figure is at best an order of magnitude estimate of the potential costs from looting. It will be an underestimate because we lack estimates for some of the thrifts on our list and because estimated resolution costs have typically been underestimates rather than overestimates. In addition, there could have been a great deal of looting that did not attract government attention. On the other hand, it could overstate the losses due to gambling and looting, because some of the total may simply represent losses from the 1970s that were carried forward.

A more direct estimate of the losses due to looting comes from a comparison of the resolution costs of mutual savings banks, which had asset structures similar to that of savings and loans, but were treated as banks rather than thrifts for historical and institutional reasons. As a result, the savings banks were subject to regulatory oversight not by the FSLIC, but by the FDIC, which moved aggressively to limit its exposure to losses from these banks in the early $1980 \mathrm{~s} .{ }^{38}$ Banking authorities did not give the mutuals new powers, liberalize the accounting treatment of their net worth, or encourage them to grow out of their difficulties. Instead, they limited the mutuals' activities, and waited the problem out.

37. O'Shea (1991, p. 31).

38. For details, see Mayer (1990, pp. 81-82). 
Table 1. Resolution Costs at Thrifts Suspected of Fraud

Present value in millions of dollars

\begin{tabular}{|c|c|c|}
\hline Savings and loan & State & $\begin{array}{l}\text { solution } \\
\text { cost }\end{array}$ \\
\hline American Diversified Savings Bank & $\mathrm{CA}$ & 798 \\
\hline American Federal of Colorado & $\mathrm{CO}$ & 339 \\
\hline American S\&L & $\mathrm{CA}$ & 1,699 \\
\hline Ameriway Savings Assoc. & $\mathrm{TX}$ & 173 \\
\hline Bell Savings Bank & PA & 189 \\
\hline Beverly Hills S\&L & $\mathrm{CA}$ & 983 \\
\hline Bexar Savings & $\mathrm{TX}$ & 483 \\
\hline Brookside Savings & $\mathrm{CA}$ & 63 \\
\hline Caguas Central FSB & PR & 120 \\
\hline Cal America & $\mathrm{CA}$ & 100 \\
\hline Capital FS\&L & AR & 23 \\
\hline Caprock S\&L & $\mathrm{TX}$ & 299 \\
\hline Cardinal Savings Bank & $\mathrm{NC}$ & 34 \\
\hline Carver S\&L Association & $\mathrm{CA}$ & 54 \\
\hline CenTrust Bank & FL & 1,705 \\
\hline Century S\&L Association & $\mathrm{TX}$ & 48 \\
\hline Charter Savings Bank & $\mathrm{CA}$ & 34 \\
\hline City Savings & NJ & 1,531 \\
\hline Colonial Federal Savings & NJ & 119 \\
\hline Colonial Savings Association & KS & 37 \\
\hline Columbia S\&L & $\mathrm{CA}$ & 1,149 \\
\hline Commerce Savings & $\mathrm{TX}$ & 604 \\
\hline Commodore Savings Association ${ }^{\mathrm{a}}$ & $\mathrm{TX}$ & 1,846 \\
\hline Commonwealth $^{\mathrm{b}}$ & FL & 325 \\
\hline Community Federal S\&L & MO & 372 \\
\hline Community S\&L & WI & 37 \\
\hline Concordia Federal & IL & 90 \\
\hline Continental S\&L & $\mathrm{TX}$ & 678 \\
\hline Cornerstone Savings & $\mathrm{TX}$ & 24 \\
\hline Creditbanc Savings $^{\text {a }}$ & $\mathrm{TX}$ & 1,108 \\
\hline Cross Roads S\&L Association & OK & 11 \\
\hline Deposit Trust Savings & LA & 21 \\
\hline First Atlantic Savings & NJ & 247 \\
\hline First California Savings & $\mathrm{CA}$ & 74 \\
\hline First Federal of Shawnee & OK & 56 \\
\hline First Federal S\&L & $\mathrm{CA}$ & 16 \\
\hline First Federal Savings Bank & WY & 11 \\
\hline First Network Savings & $\mathrm{CA}$ & 139 \\
\hline First Savings Assoc. of East Texas & TX & 88 \\
\hline First Savings Bank and Trust & MO & 3 \\
\hline First State Savings & $\mathrm{TX}$ & 271 \\
\hline First $\mathbf{S} \& \mathbf{L}$ of Toledo & $\mathrm{OH}$ & 128 \\
\hline First Texas/Gibraltar Savings ${ }^{a}$ & $\mathrm{TX}$ & 5,034 \\
\hline Franklin Savings (Creditbanc) ${ }^{a}$ & $\mathrm{TX}$ & $\ldots$ \\
\hline
\end{tabular}


Table 1. (continued)

Present value in millions of dollars

\begin{tabular}{|c|c|c|}
\hline Savings and loan & State & $\begin{array}{c}\text { Resolution } \\
\text { cost }\end{array}$ \\
\hline Freedom S\&L Association & FL & 349 \\
\hline Frontier Savings $^{\mathrm{a}}$ & OK & 279 \\
\hline General Savings Association & $\mathrm{TX}$ & 18 \\
\hline Gibraltar & $\mathrm{CA}$ & 522 \\
\hline Gold River Savings ${ }^{b}$ & $\mathrm{CA}$ & 3 \\
\hline Great West Savings & $\mathrm{CO}$ & 7 \\
\hline Gulf Federal & LA & 176 \\
\hline Hill Financial Savings Association & PA & 657 \\
\hline Home Savings & $\mathrm{AK}$ & 45 \\
\hline Imperial Savings & $\mathrm{CA}$ & 1,647 \\
\hline Independence Federal & $\mathrm{AR}$ & 291 \\
\hline Independent American ${ }^{a}$ & $\mathrm{TX}$ & 6,111 \\
\hline \multicolumn{3}{|l|}{ Interwest Savings Association } \\
\hline Lamar Savings Association ${ }^{\mathrm{a}}$ & $\mathrm{TX}$ & 2,115 \\
\hline Liberty Federal & NM & 80 \\
\hline Libertyville Federal S\&L & IL & 9 \\
\hline Lincoln S\&L & $\mathrm{CA}$ & 2,824 \\
\hline MeraBank & $\mathrm{AZ}$ & 1,023 \\
\hline Mercury Savings & $\mathrm{CA}$ & 34 \\
\hline Mercury Savings ${ }^{a}$ & $\mathrm{TX}$ & 1,327 \\
\hline Meridian Savings & $\mathrm{TX}$ & 418 \\
\hline MeritBanc Savings & TX & 211 \\
\hline Midwest Federal & MN & 826 \\
\hline Mission Savings & $\mathrm{TX}$ & 65 \\
\hline Multibanc (Independent American) & TX & $\ldots$ \\
\hline Northpark Savings (Commodore) ${ }^{a}$ & TX & $\ldots$ \\
\hline Odessa Savings ${ }^{\mathrm{a}}$ & $\mathrm{TX}$ & 1,490 \\
\hline Otero Savings & $\mathrm{CO}$ & 257 \\
\hline \multicolumn{3}{|l|}{ Paris S\&L Association } \\
\hline$(\text { Mercury })^{\mathrm{a}}$ & $\mathrm{TX}$ & $\ldots$ \\
\hline Peoples Bank for Savings & IL & 18 \\
\hline Peoples Heritage Federal Savings & KS & 958 \\
\hline Peoples Homestead Federal & LA & 98 \\
\hline Peoples Savings $^{\mathrm{a}}$ & $\mathrm{TX}$ & 343 \\
\hline Phoenix Federal & $\mathrm{AL}$ & 74 \\
\hline Pima S\&L & $\mathrm{AZ}$ & 319 \\
\hline Resource Savings Association & TX & 278 \\
\hline Richardson Savings (Mercury) ${ }^{\mathrm{a}}$ & TX & $\ldots$ \\
\hline Royal Palm Savings & FL & 154 \\
\hline San Angelo Savings (Odessa) ${ }^{a}$ & TX & $\ldots$ \\
\hline San Jacinto Savings & TX & 1,424 \\
\hline Saratoga Savings & $\mathrm{CA}$ & 11 \\
\hline Security Savings & TX & 468 \\
\hline Skokie Federal & IL & 168 \\
\hline
\end{tabular}


Table 1. (continued)

Present value in millions of dollars

\begin{tabular}{|c|c|c|}
\hline Savings and loan & State & $\begin{array}{l}\text { Resolution } \\
\text { cost }\end{array}$ \\
\hline Stockton Savings (Lamar) ${ }^{\mathrm{a}}$ & $\mathrm{TX}$ & $\cdots$ \\
\hline Sun S\&L Association & $\mathrm{CO}$ & 157 \\
\hline \multicolumn{3}{|l|}{ Sunbelt Savings of Texas } \\
\hline (Independent American) $^{\mathrm{a}}$ & $\mathrm{TX}$ & $\ldots$ \\
\hline Territory S\&L Association & $\mathrm{OK}$ & 46 \\
\hline TexasBanc & $\mathrm{TX}$ & 308 \\
\hline Trinity Valley & $\mathrm{TX}$ & 12 \\
\hline United Savings Association of Texas & $\mathrm{TX}$ & 1,374 \\
\hline United Savings & NJ & 25 \\
\hline United Savings & VA & 112 \\
\hline United Savings & WY & 147 \\
\hline United Savings of America & FL & 26 \\
\hline United Savings Bank & $\mathrm{MN}$ & 31 \\
\hline Unity Savings & $\mathrm{CA}$ & 57 \\
\hline Universal Savings & $\mathrm{TX}$ & 223 \\
\hline University Federal Savings Association & TX & 2,557 \\
\hline Victoria Savings & TX & 782 \\
\hline Vision Banc & $\mathrm{TX}$ & 64 \\
\hline Western Savings & $\mathrm{AZ}$ & 1,728 \\
\hline Western Savings (Independent American) (a.b $^{\text {a }}$ & $\mathrm{TX}$ & $\ldots$ \\
\hline Westport Savings & $\mathrm{CA}$ & 20 \\
\hline Williamsburg Federal S\&L & UT & 37 \\
\hline Total resolution costs: & & 53,966 \\
\hline
\end{tabular}

Source: Names on the list are taken from two main sources: a Resolution Trust Corporation (RTC) list of prosecutions already initiated or completed, taken from U.S. Senate (1991); and the RTC's "Top 100" list of priority cases for prosecution, as leaked in David Johnson, "S\&L Criminal Inquiries Confirmed," New York Times, October 3,1990 , p. D4. We also added two thrifts-United Savings of Texas and Gilbraltar of California-that feature prominently in the FDIC lawsuit against Michael Milken and Drexel Burnham Lambert.

Estimated resolution costs are taken from FSLIC tables in U.S. Senate (1990), from the 1990 and 1991 RTC annual reports, and from an RTC Resolved Conservatorship Report of December 1992. For Cal America, costs are from U.S. House of Representatives (1987). This table includes cases of possible fraud still under consideration that were current at the time that the source documents were published (1990 and 1991). It thus excludes a number of prominent cases-Vernon Savings and Empire Savings in Texas, for example-in which prosecutions came earlier.

a. Thrifts sold by FSLIC as part of a group of thrifts. If a cost is listed, it is the cost for the entire group, not this thrift alone. If a cost is not listed, the name of the thrift giving the cost for the group appears in parentheses.

b. The original source note carries the cryptic note "unable to make specific identification."

In 1982, the savings banks had assets that were 25 percent of the assets at savings and loans. ${ }^{39}$ From 1981 to 1986 , the FDIC spent about $\$ 7$ billion to rescue and recapitalize ailing savings banks. ${ }^{40}$ If this experience is any guide, the entire thrift crisis could have been solved at a cost of about $\$ 28$ billion by following a strategy parallel to the one adopted by

39. Federal Reserve Bulletin, July 1984, p. A26.

40. Based on personal communication with G. K. Gibbs. 
the FDIC of limiting the activities of insolvent institutions and resolving them over time as reductions in interest rates increased the value of mortgage assets.

Another way to construct an estimate of the losses caused by the combination of the regulatory treatment given to thrifts and the perverse incentives that this created for owners is to compare the resolution costs at stockholder-owned S\&Ls with the costs at mutual S\&Ls, where the depositors were the legal owners. Because the true owners of the mutuals were more dispersed and faced greater difficulty in controlling the behavior of management and in capturing the gains from looting or gambling in the form of direct payouts, management at the mutuals had much less incentive to pursue strategies that gave shareholders a current gain but that risked their jobs. Consistent with this theory, Benjamin C. Esty has found that stock thrifts failed at three times the rate ( 26.8 percent) as mutual thrifts (8.1 percent) between 1983 and $1988 .{ }^{41}$

A comparison of the costs at mutual thrifts and stock thrifts similarly suggests that the costs of resolving the thrift crisis could have been in the range of $\$ 20-\$ 30$ billion. In 1982, mutual S\&Ls had about two times as many assets as stock S\&Ls. If there had been no incentive to loot, the behavior of the two types of thrifts should have been the same and the costs of resolving the stock thrifts should have been about half the cost of resolving problems at the mutuals. But in fact, the incentives faced by managers in the two different kinds of institutions were quite different; their behavior reflects this difference. While the total quantity of assets held by the mutuals stayed almost constant from 1982 to 1987, assets at the stock thrifts grew more than four-fold..$^{42}$ Because losses were incurred on many of the investments made by the stock thrifts during this period of growth, a small problem at the stock S\&Ls grew into a very big problem.

To estimate what the resolution costs for the S\&Ls would have been if thrift regulators had followed the conservative strategy of the FDIC, we calculated what total resolution costs would have been if all thrifts had behaved like the mutuals after 1982 . We used the Treasury bill rate to convert costs incurred in different years into a common unit, 1982 dollars. (Because the thrifts typically had to pay a premium over the Trea-

41. Esty (1992, table 1, panel B).

42. See Barth (1991, table 3-8, p. 57). 
sury bill rate to attract brokered deposits, the use of this rate makes our estimate of the cost slightly larger than if we used their actual cost of funds. In this sense, our use of the Treasury bill rate is conservative.) If we apply the resulting estimate of the cost per dollar of assets at the mutuals to all assets in the S\&L industry, we find that the total cost of resolution would have been $\$ 26.8$ billion in 1982 dollars. ${ }^{43}$

Four remarks should be made about this calculation. First, resolving the problem earlier makes the current dollar cost smaller because the resolution cost will grow with the interest rate. If we use the three-month Treasury bill rate to bring a $\$ 26.8$ billion cost in 1982 forward to 1993, the costs would be slightly less than $\$ 60$ billion, or $(2.15 \times \$ 26.8$ billion). This number can be compared to an actual cost (that has been converted into 1993 dollars) of $\$ 140$ billion.

Second, the $\$ 26.8$ billion total cost of resolving problems in the thrift industry includes looting and excessive risk-taking at mutuals. To make a rough adjustment for this, we calculated the fraction of losses of mutuals from the list of suspect thrifts in table 1. Mutuals accounted for 8 percent of the costs in this group. Stock thrifts accounted for the other 92 percent. Using this percentage to calculate an estimate of avoidable losses from 1982 to 1993 at the mutuals reduces our estimate of the cost by about $\$ 4$ billion in 1982 dollars.

Third, the estimate assumes that mutuals that were converted to stock ownership during this period and that were resolved later had nonnegative net worth at the time when they were converted. We think that this is a reasonable assumption. In a conversion, existing depositors are offered the opportunity to purchase shares in the new stock thrift. A dispersed group of investors who do not expect to be able to loot would not pay to invest in a thrift that had a negative net worth. Moreover, the bank board, which had to approve all conversions, required that the net worth of the institution be positive and that the price for the shares in the new institution be fair. These rules, together with restrictions on the amount of equity that could be acquired by insiders, would have made it inconvenient to convert a mutual with a large negative net worth into a stock thrift with the intention of gaining control and looting it.

43. The assets and resolution costs of the mutual and stock $S \& L$ s are taken from Barth (1991) and our calculations of resolution costs for 1990 and 1991 from annual reports of the Resolution Trust Corporation. We are grateful to James Barth for providing updated tables of the resolution costs in his book. 
Fourth, we truncated the resolution costs in 1991, the last year for which data are available. Using the Treasury bill rate to convert costs incurred in different years into costs in 1993, the total resolution costs incurred in the years for which we have data are $\$ 140$ billion, which is close to the total estimated costs for the bailout of about $\$ 150-\$ 175$ billion reported by the National Commission on Financial Institution Reform, Recovery, and Enforcement. ${ }^{44}$ Thus we expect that our data cover the bulk of total costs that the government will incur. In any case, the comparison of the approximately $\$ 60$ billion in 1993 costs for thrifts covered in our data versus $\$ 140$ billion in actual costs is valid. Because the costs at the mutuals tended to be resolved earlier than costs at the stock thrifts, we expect the final totals will primarily reflect additional costs at stock thrifts rather than additional costs at the mutuals. If so, the final tally for the costs of letting the stock thrifts behave as they did will be even higher than our calculations suggest.

\section{Boom and Bust in Dallas}

We described earlier how S\&Ls could be looted in symbiotic deals with parasitical developers who would also go bankrupt. This section develops a model of this activity and shows how a small amount of such looting by S\&Ls can be the impulse-through a multiplier-that induces a bubble in building activity and land prices. This bubble will be fueled by honest developers who fail to understand the source of the additional demand caused by looters and parasites. We call these developers copycats because they infer the implicit rents from building by watching the market price for land; they are thus analogous to the investors in the stock market who do not collect fundamental information, but merely purchase the market portfolio. ${ }^{45}$ Unfortunately for the copycat developers, when the demand for land expands because of looting, they fail to understand the source of the rise in price. The copycats act on the principle that if a crowd is staring at the sky, they too should look, be-

44. National Commission on Financial Institution Reform, Recovery, and Enforcement (1993, p. 4).

45. For recent models in which agents infer the value of important signals by watching others, see Banerjee (1993), Bikchandani, Hirshleifer, and Welch (1992), Caplin and Leahy (1991), and Romer (1993). 
cause there must be something to see- otherwise the crowd would not be staring so intently. Most of the time this behavior is correct. When it is wrong, it eventually comes to an abrupt halt.

\section{The Model}

We start with a simple model of land prices, and initially, no looters. There are two types of developers. The first, who comprise a fraction $(1-\beta)$ of the market, have a demand that depends only on a shift parameter, $A$, and on the price for land, $p$. Their demand, $D_{1}$, is

$$
D_{1}=(1-\beta)(A-b p) \text {. }
$$

The shift parameter, $A$, reflects fundamentals such as the number of people moving into the city or region, the expected incomes of the residents, and other exogenous factors. This first type of developer knows the value of $A$.

Developers of the second type, who together form a fraction $\beta$ of the market, do not know the true value of $A$, but estimate it from signals inferred from the activities of others. Their demand, $D_{2}$, is similar to the demand by type 1 developers, but their estimate of the shift parameter is $A^{e}$ :

$$
D_{2}=\beta\left(A^{e}-b p\right) \text {. }
$$

In our simple model, parallel to Grossman's fully revealing rational expectations model, we assume that these type 2 developers infer the true value of $A$ from the market price for land. ${ }^{46}$ In other words, $A^{e}$ is estimated from an equation of the form

$$
A^{e}=\delta+\gamma p .
$$

We assume that this estimate of $A^{e}$ is rational, so the parameters $\delta$ and $\gamma$ in this expression must be chosen so that this yields an unbiased estimate for $A$.

The supply of land to developers, $S$, which is generated outside the model, is upward-sloping, of the form

$$
S=d+e p,
$$

where $p$ is the price and $d$ and $e$ are parameters.

46. Grossman (1976). 
Equating supply with demand in this land market yields an equilibrium price for land that is a function of the parameters in the expression for $A^{e}$. Matching coefficients so that $A^{e}$ is equal to $A$ implies that $\delta=d$ and $\gamma=b+e$. With these values substituted in, the demand for land by copycat investors can be written as

$$
D_{2}=\beta(d+e p) .
$$

The copycats' reduced-form demand is increasing in price because price increases signal increases in market fundamentals. Moreover, in equilibrium, they purchase a fraction $\beta$ of all the land that is sold for development. That is, they exactly replicate the behavior of the market as a whole, just as index investors buy their share of the stock market.

This supply and demand system describes a very simple rational expectations equilibrium. Now consider a new equilibrium with a change in regulations, so that looters at S\&Ls will offer new loans in the amount $N$ to parasitical developers who are new entrants and who have no interest in making a profit. Initially, before agents adjust the parameters in their expectations function, how will the equilibrium price change? Who will gain and who will lose? And by how much?

To simplify the model, we assume that the parasitical developers take out loans only for building, and that one parcel of land requires $B$ dollars of building. The direct effect of the looting is an increase in the demand for land by an amount $D_{3}=N / B$. The new equilibrium equates the new total demand $D_{1}+D_{2}+D_{3}$ to the supply $S$. The looters at the S\&Ls and the parasitical developers have every reason to conceal their true intent, so we assume that the honest but uninformed developers do not recognize the parasites as new entrants into this market; these honest developers therefore continue to use the same rule as before to infer the fundamentals from the market price. The informed developers, of course, continue to observe the true value of $A$. This combination of circumstances will lead directly to a real estate boom and bust. We shall now describe the new equilibrium (and its collapse).

To the copycat developers, it appears that the fundamental shift parameter $A$ has increased by the amount

$$
[1 /(1-\beta)](N / B) \text {. }
$$

The price of land increases by

$$
[1 /(1-\beta)](N / B)[1 /(e+b)] .
$$


The quantity of land that is developed increases by the slope coefficient $e$ (from the supply equation) times this price change. Note that these increases vary inversely with the fraction of fundamental developers, $1-\beta$. If the fundamental developers comprise only 10 percent of the market, the effect of the new demand stemming from the symbiotic relationship between looters and parasites is ten times what it would be if all developers were fully informed.

In the new equilibrium, the fundamental investors withdraw from the market. Given the price increase they observe and the unchanged estimate of the market fundamentals, they reduce their purchases of land by $(1-\beta) b$ times the price increase. The copycat investors increase their purchases of land by an amount equal to $\beta e$ times the price increase.

Now suppose that the true value of $A$ is revealed (through persistently high vacancy rates, for example); that the parasitical developments are taken over by regulators and sold on the open market; and that savings and loans are prohibited from engaging in this kind of looting. Because building is irreversible, the price of developed real estate falls below the level before the looters began to finance development. The parasitical developers go bankrupt, as expected. In addition, however, so do some of the fundamental and copycat investors, who take capital losses because of the unexpected price decline. In an extended model of a growing economy, the normal pace of construction activity would be interrupted for several years, with no new building taking place until the local demand had increased to meet the excess supply.

\section{The Evidence}

Our model and the sequence of events it portrays describes the building boom of the 1980s in Dallas, the center of activity for the Texas thrifts. The comparison with Houston is illuminating. For both cities, table 2 reports construction activity and vacancy rates for office space. The construction peaks occurred earlier in Houston than in Dallas/Fort Worth, with office construction peaking in 1983 in Houston, but not until 1985 in Dallas/Fort Worth. The timing of these peaks can be explained partly by the differences in the economies of the two cities. Houston's economy is oil-based, while Dallas/Fort Worth's is much more diversified. For example, in Houston 45 percent of office space is occupied by 
Table 2. Office Construction and Vacancy Rates for Dallas/Fort Worth and Houston, 1981-90

\begin{tabular}{lccccc}
\hline & \multicolumn{2}{c}{ Dallas/Forth Worth } & & \multicolumn{2}{c}{ Houston } \\
\cline { 2 - 3 } \cline { 5 - 6 } Year $^{\text {Construction }^{\mathrm{a}}}$ & Vacancies $^{\mathrm{b}}$ & & Construction $^{\mathrm{a}}$ & Vacancies $^{\mathrm{b}}$ \\
\hline 1981 & 7,739 & 8 & 17,193 & 6 \\
1982 & 14,750 & 11 & & 22,490 & 8 \\
1983 & 14,928 & 20 & & 29,230 & 20 \\
1984 & 10,843 & 19 & & 10,900 & 24 \\
$1985^{\mathrm{c}}$ & 20,000 & 23 & & 3,500 & 24 \\
1986 & 14,090 & 32 & & 4,301 & 32 \\
1987 & 7,290 & 32 & & 626 & 29 \\
1988 & 2,328 & 32 & & 756 & 26 \\
1989 & 1,807 & 27 & 543 & 24 \\
1990 & 831 & 24 & 837 & 21 \\
\hline
\end{tabular}

Source: Urban Land Institute (1986, 1990, and 1991).

a. Thousands of square feet.

b. Percent of total.

c. Figures for 1985 are estimates.

energy-related firms, compared to 10.5 percent in Dallas/Fort Worth. ${ }^{47}$ The near-coincidence of the rise and fall in oil prices and construction suggests that oil price changes were the likely cause for the boom and bust in Houston nonresidential and residential construction.

But while the difference in economies may explain why Dallas/Fort Worth peaked later than Houston, it does not explain why significant new construction continued in Dallas/Fort Worth even after high vacancy rates had set in. ${ }^{48}$ By 1983, the office vacancy rate in Dallas/Fort Worth had already reached 20 percent, a rate that equaled Houston's. Indeed, from 1986-90, Dallas/Fort Worth vacancy rates were at least as high as those in Houston. Yet significant amounts of building continued until 1988.

The excess of S\&L lending is very clear from a comparison with bank lending. Between 1982 and 1986, the assets of Texas commercial banks grew by 27 percent; by contrast, the assets at the Texas S\&Ls grew by

47. Steve Brown, "City Review: Dallas," National Real Estate Investor News, October 1986, p. 180.

48. Changes in the deductibility of real estate losses in the Tax Reform Act of 1986 could possibly explain the end of the office building boom. Our problem, however, is not to explain why the boom ended, but rather why with vacancy rates in excess of 20 percent, it continued in Dallas/Fort Worth for so long. 
99 percent, and those of the notorious "Texas 40 " S\&Ls grew by 299 percent ${ }^{49}$ while real estate loans grew almost as fast as total assets.

The after-effects of the building spree are certainly consistent with our model's prediction of widespread bankruptcy after the collapse, even for banks and developers who were not party to looting. In 1987, when the resolution of the crisis was beginning, S\&Ls in Texas had a very high delinquency rate of 29 percent on real estate loans, which is unsurprising given the behavior described in our model. But even at Texas banks-which were more tightly regulated-13 percent of the real estate loans were nonperforming, a level that had not been reached since the Great Depression. ${ }^{50}$

Our hypothesis is that many real estate loans were made by the thrifts without serious regard as to whether they would default. It appears to be conventional wisdom among bankers that loans with high rates are very likely to default, as illustrated by the case of FCA discussed earlier. Among Texas thrifts, those that later failed had average mortgage interest rates 76 basis points higher than the mortgage rates of thrifts that remained solvent. Moreover, the S\&Ls that grew particularly fast were particularly likely to have high mortgage lending rates. Of the Texas S\&Ls that ultimately became insolvent, the thirty-five that grew at rates of more than 50 percent per year between 1980 and 1984 had an average lending rate 148 basis points in excess of the S\&Ls that remained solvent. ${ }^{51}$ The higher rates were only one of the methods used to loot S\&Ls. As noted above, fee income, for which it is more difficult to gather data, was apparently even more important.

The tale we have told can be traced through the city reports on Dallas in the National Real Estate Investor News (NREIN). As early as June 1982, developers who seem to correspond to the informed developers in our model realized that something was going on and openly expressed their concern. For example, in a NREIN story subtitled "Experts Concerned About Huge Supply Pipeline," Mark Pogue of Dallas' Lincoln Properties said, "All of us need to be more cautious. . . . How will this market absorb these millions of square feet?"52 A year later, in June

49. U.S. House of Representatives (1990, p. 213).

50. Short and Gunther (1988, table 4, p. 5).

51. Short and Gunther (1988, table 3, p. 3) and personal communication.

52. Steven Brown, "Office Market Outlook: Dallas," National Real Estate Investor News, June 1982, p. 46. 
1983, Dallas ranked second nationally to Houston in vacant office space. ${ }^{53}$ At the same time, paradoxically, it was first in office construction. In October 1983, McDonald Williams of Trammell Crow, one of the county's most successful and respected developers, warned about the overbuilding and put the blame to a considerable extent on "the push that savings and loans are making into commercial real estate . . . They are going to keep us overbuilt, I think." ${ }^{54} \mathrm{He}$ also blamed institutional investment funds, which correspond to the copycat suppliers of funds in our model. A year later, with the NREIN reporting that "old timers in Dallas [were] amazed at the surge in construction," ${ }^{55}$ Dan Arnold of Swearingen Company provided his explanation of the continued activity: "Financial institutions and lenders have money that must be placed." ${ }^{56}$ Still later, in June of 1985 Wayne Swearingen could not explain why the rising vacancies had not led to a slowdown in office construction. "We have developers sitting there with empty buildings, and the lenders are giving them money to start another one. I have to blame the lenders. I want them to show me where these builders are going to get cash flow. . . The laws of supply and demand are not governing market behavior. Continuing construction in the face of high vacancy seems related to the availability of financing for new buildings, rather than need." 57

He was speaking just before the crash removed any doubt that there was a problem. Our model suggests that he had the diagnosis exactly right.

\section{Looting, Junk Bonds, and Takeovers}

This now leads us to our final question. An even more dramatic development in North America during the 1980s than the boom and bust in

53. Steve Brown, "City Review: Dallas," National Real Estate Investor News, June 1983 , p. 60.

54. Steve Brown, "City Review: Dallas," National Real Estate Investor News, October 1983 , p. 127.

55. Steve Brown, "City Review: Dallas," National Real Estate Investor News, October 1984, p. 183.

56. Steve Brown, "City Review: Dallas," National Real Estate Investor News, October 1984, p. 192.

57. Steve Brown, "City Review: Dallas," National Real Estate Investor News, June 1985, pp. 98-100. Italics added. 
real estate was the rise and decline of junk bonds and debt-financed corporate takeovers. Is there a link between bankruptcy for profit in S\&Ls, junk bonds, and takeovers?

At first glance, such a link appears implausible because the value of junk bonds held by S\&Ls was small compared to the total junk bond market, and very small compared to the total quantity of assets that changed hands. Even at the peak, S\&Ls held only about $\$ 13.2$ billion of junk bonds ${ }^{58}$ whereas the total outstanding issues of junk bonds exceeded $\$ 200$ billion by $1989 .{ }^{59}$ During the entire decade of the 1980 s, the total value of assets changing hands in takeovers was $\$ 1.3$ trillion. ${ }^{60} \mathrm{How}$ could a relatively small amount of junk bond purchases by thrifts have had any significant effect on the junk bond market as a whole, and indirectly on the volume of takeovers?

In this section, we suggest that a particular form of S\&L looting indeed influenced the timing and volume of takeover transactions. The first part of this argument rests on the assertion, articulated for example by Michael $C$. Jensen, that the creation of the junk bond market did encourage the takeover wave of the $1980 \mathrm{~s} .{ }^{61}$ The ability demonstrated by Drexel Burnham Lambert in the 1980s to raise billions of dollars in only a few days lent credibility to takeover bids for large firms that never before could have been financed. Even though junk bonds provided only part of the ultimate financing for the totality of takeover transactions, "highyield bonds are an important innovation in the takeover field because they help eliminate size as a deterrent to takeover," as Jensen has argued. ${ }^{62}$

The second part of our argument is that the funds made available by the owners of S\&Ls who were interested in looting made it possible to reduce artificially the interest rate on junk debt underwritten by Drexel. ${ }^{63}$ Potential purchasers of Drexel debt could observe two key sig-

58. See Yago (1991, p. 187).

59. Investor's Digest Daily, as cited in Yago (1991, p. 199).

60. Andrei Shleifer and Robert W. Vishny, "The Takover Wave of the 1980s," Science 249, August 17, 1990, p. 745.

61. Jensen (1988).

62. Jensen (1988, p. 39).

63. As far as we know, Benjamin Stein was the first person to emphasize the importance of the links between the savings and loans and the junk bond market. His argument first appeared in a series of articles published in Barron's in the late 1980s. For a summary of his case, see Stein (1992). 
nals concerning the quality of its offerings: the success rate of its underwritings and the default rate on its outstanding issues. Our claim is that relatively small amounts of other people's money could be used to manipulate these two signals and thereby cause Drexel borrowers to pay a lower interest rate than they otherwise would have had to pay.

We will show that unusual circumstances provided an opportunity for successful manipulation of the junk bond market. We will also show that there were many tell-tale signs consistent with the actual occurrence of such market manipulation. Before turning to the details in this argument, we place it in the context of the popular and scholarly literature on takeovers.

Our story of looting and takeovers has nothing to do with the journalistic accounts of a takeover artist who acquires control of a firm and then "loots" it. Victor Posner is the person most frequently cited as an example of this type of corporate looter, with a personal take from companies under his control reportedly in excess of $\$ 23$ million in $1984 .{ }^{64}$

The vast bulk of takeover activity cannot be explained in this naive fashion. Detailed accounts of transactions such as the RJR-Nabisco takeover give ample evidence of serious attention to the true economic returns of the deal under consideration. ${ }^{65}$ Furthermore, too many sophisticated investors invested in takeovers and had no access to fee income or excessive compensation. ${ }^{66}$

A theory of the takeover wave must therefore be consistent with serious attempts at value-maximization by the investors in takeovers. As noted above, our claim is that looting strategies followed by S\&Ls could have led to reduced yields paid on junk bonds, which made debt-financed takeovers more attractive to rational investors.

\section{Market Manipulation}

Under normal circumstances, large markets cannot be manipulated for profit by small groups of individuals. Historically, attempts to domi-

64. Stewart (1992, p. 121).

65. See Burrough and Helyar (1990, pp. 363-66).

66. For a discussion of the underlying fundamentals that help explain why takeovers were attractive, and why many corporations needed restructuring during the 1980 s, see Jensen (1988), Scherer (1988), Shleifer and Vishny (1988), and Andrei Shleifer and Robert W. Vishny, "The Takeover Wave of the 1980s," Science 249, August 17, 1990, pp. 745-49. 
nate the U.S. grain, gold, and silver markets have borne out this insight of economic theory. They have led to the downfall, rather than the making, of ambitious speculators. In this section, we argue that conditions in the junk bond market of the 1980s were not normal. Both the structure of information and the availability of other people's money-that is, taxpayers' money controlled by the looters of financial institutions-offered unique opportunities for profitable manipulation of a large-scale market. We wish to show that the evidence is sufficient to give the case for market manipulation its day in court.

The junk bond market of the 1980s was not a thick, anonymous auction market characterized by full revelation of information. To a very great extent, the market owed its existence to a single individual, Michael Milken, who acted, literally, as the auctioneer. Milken created a new securities market that lent funds to firms that had previously been able to borrow only from banks. The market for new issue bonds below investment grade was trivially small prior to the 1980 s presumably because of the inherent difficulty in controlling opportunistic behavior when a limited liability corporation borrows money. As we noted above, private lenders face the same difficulties as the government faces in lending to an entity that can declare bankruptcy; borrowers can take the money and run. We also noted that economists presume that opportunistic behavior has somehow been controlled in cases where private lending does take place. An obvious corollary is that opportunistic behavior has not been controlled in cases where apparently profitable lending does not take place. The absence of a large-scale market in securitized risky debt prior to the 1980 s presumably reflects an inability to resolve these problems through any institutional arrangement other than bank lending, in which the lender and the individual engaged in monitoring the borrower are part of a single organization.

\section{Milken as Loan Broker}

The claim that Milken made in the 1980s was, in effect, that he could play the role of both filter and monitor in a securities market for risky debt. He would identify creditworthy borrowers who were willing and able to pay very high yields and he would verify that they did as they promised with the proceeds. (In this second connection, it is puzzling that high-yield bonds in the 1980s typically carried fewer covenants and 
restrictions than conventional corporate debt, ${ }^{67}$ so Milken's control over these firms would presumably have operated through other mechanisms.)

To take advantage of his putative strengths in evaluating and monitoring borrowers, Milken could have had Drexel take the role of a bank, holding the high-yield debt from these firms and earning a spread over Drexel's borrowing costs. But instead of operating like a banker, Milken earned income for himself and for Drexel by charging a commission on all the loans that he arranged between the borrowers and a diverse set of lenders and, allegedly, sharing in the gains from the takeovers made possible by this debt.

In creating this new market for securitized bank loans, Milken faced a serious credibility problem. Loan brokers, who match borrowers and lenders in exchange for a commission, have a deservedly bad reputation. The incentive to match bad credits with gullible lenders and to walk away with the initial fees is very high. It can also take several years for this kind of scheme to be detected because even a bad creditor can set aside some of the initial proceeds from a loan to make several coupon or interest payments. Proponents of junk bonds as "securitized bank loans" therefore have to argue not only that Milken had unique abilities in evaluating credit risk and making judgments about borrowers, but also that he was somehow able to establish a reputation for competence and reliability with the investors who bought his issues.

In retrospect, it is not easy to make the case that Milken succeeded in establishing his credibility as a loan broker because of an exceptional ability in making judgments about his borrowers. Even at the time, it was clear that Milken made many questionable judgments about borrowers, his initial support and continued backing of Posner being just one particularly salient example.

The most likely explanation for investors' faith in Milken was demonstrated success. Until 1987, when the threat of prosecution became a serious concern, Milken had demonstrated two remarkable kinds of success. The default rate on his junk bonds had been very low compared to the premium over investment grade bonds, and the success rate of his underwritings had been very high. Given the private nature of the junk bond market, these were the only observable signals that an investor

67. Asquith and Wizman (1990). 
could use to judge Milken's performance, and by these measures, he had done extremely well. William Seidman recalls his perceptions at the time:

A phenomenon that mystified me when I was dean of the Arizona State University Business School was: How did Drexel Burnham Lambert and its star partner Michael Milken roll up an unparalleled record of successes in selling junk bonds? As far as we could determine, his underwritings never failed and appeared to be marketed successfully, no matter how suspect the company or how risky the buyout deal that was being financed. Other investment houses had some failed junk bond offerings, but Drexel's record was near perfect. We directed our faculty to research the matter. . . . The faculty came up with no plausible explanation; like so many others they fell back on the thesis of the junk bond king's unique genius. ${ }^{68}$

If we view Milken as someone who invested in a reputation for delivering good returns to purchasers of his debt, it is clear that an unblemished record of delivering on his promises was essential to maintaining this reputational equilibrium. We suggest that Milken may have been able to sustain such a record of successful underwritings and low default rates by manipulating the market.

\section{Purchases by Partnerships}

The complaint brought by the FDIC against Milken and his associates gives an explanation of the near-perfect record of underwriting successes. ${ }^{69}$ According to the complaint, Milken formed more than 500 different partnerships that purchased securities in public offerings underwritten by his employer. The complaint reports that in the first half of 1988 , the partnerships and Drexel insiders made more than 14,000 purchases through 6,000 different accounts from Drexel public offerings. These purchases could serve several purposes. They could ensure that all public offerings were fully subscribed. They could also be used to mark up prices on bonds or strip the equity kicker from a bond before it was sold to the public, thereby hiding from both the issuers and the purchasers the true profits of Drexel and Milken on any deal. Participation in a partnership that was guaranteed to make a profit could also be used as an inducement for managers at mutual funds and savings and

68. Seidman (1993, p. 235).

69. FDIC v. Milken (1991). 
loans to buy overvalued or unusually risky junk debt for their institutions.

Jesse Kornbluth reports the details of one transaction that illustrates one way in which large profits could be extracted through the partnerships. ${ }^{70}$ When Kohlberg Kravis Roberts (KKR) engaged in its bidding war for Storer Communications, the partnership relied on assurances that Drexel could finance the deal. For KKR to beat its rival, Milken was ultimately forced to raise $\$ 1.466$ billion in two days to finance a purchase that many professionals thought was too expensive..$^{71}$ This was also the first time that Milken had needed to raise sums this large on such short notice. Milken told KKR that it would have to bundle "equity sweeteners"-warrants-with the debt to be able to finance the deal. Milken had Drexel sell the bundled debt and warrants to various partnerships that he controlled. These partnerships kept the warrants, but sold the debt to outsiders. The warrants on this deal generated about $\$ 172$ million in profit. Milken-controlled partnerships secretly kept more than 80 percent of these warrants. ${ }^{72}$

It is dubious that secret purchases paid by Milken would have been sufficient to manipulate the junk bond market profitably. Someone who wanted to engage in market manipulation would ideally like to have access to large captive pools of financial assets. These assets would provide back-up funds sufficient to ensure that any new issue could be absorbed and moved rapidly from partnership accounts to outside accounts. Furthermore, these captive pools could be used to reduce the observed default rate by having them provide new long-term financing to companies that were truly bankrupt. Outstanding bonds could have been exchanged for new bonds held by the pools of the captive institutions. Or these companies could have been infused with new capital by a junk bond issue.

It is this possibility-that looters at savings and loans helped defer default and reduce observed default rates-that we consider next. Bribes to managers of mutual funds could be used to achieve the same effect, but we will focus on savings and loans because of our interest in the economywide effects of the incentives for looting created by government guarantees.

70. Kornbluth (1992).

71. See Bruck (1989, p. 176).

72. Kornbluth (1992, pp. 323-24). 


\section{The Potential Profits from Broker Manipulation}

Under normal circumstances, it would not pay a securities broker to use his or her own resources to change default rates in order to increase the demand for his product. The costs of the manipulation would normally overwhelm any recapture through increases in the broker's commissions. However, the late 1980 s provided unique opportunities. The availability of S\&Ls to be looted made the junk bond market ripe for manipulation.

A comparison of the prospective benefits to buyers of bonds and the prospective increases in commissions to bond brokers shows that a broker cannot normally increase his or her profits by purchasing at par any bonds that are about to go into default and absorbing the losses. This absorption would increase the demand for bonds, which would increase the broker's commissions, but almost invariably by less than the refinance cost to reduce the default rate on previously issued bonds.

The argument goes as follows. The expected benefit to buyers of currently issued bonds from the manipulation of default rates is the expected reduction in future losses. In a steady state, with constant new issues of bonds, the payments made on previously issued bonds will exactly correspond to the reduction in expected future losses on bonds that are currently issued, if buyers' expectations of future default losses are formed by the historical experience of past default losses. Because these expected reductions in losses are in the future but the payments by the broker-manipulator are in the present, the buyers' discounted expected gains will be less than the cost to the manipulator of changing the historical default rates. Only if the number of bonds issued in the past is considerably less than the volume of current issues will the buyers' increased valuation of the bonds exceed the brokers' costs. The broker-manipulator also faces a problem in that he will typically be able to capture only a small fraction of the increase in the market value that his expenditures create.

If buyers extrapolate the artificially low rates of default, faster growth of the market reduces the costs of manipulation relative to buyers' expected gains because it reduces the number of previously issued bonds whose losses must be absorbed relative to currently issued bonds. If the total quantity of bonds outstanding grows at the rate of interest on the junk bonds and if expectations of future default rates are determined by 
current default rates, the increase in the market value of the newly issued bonds induced by the manipulation will just equal the broker's cost of absorbing default losses. If the market grows faster than the rate of interest, the expected gains in the value of the new bonds will exceed the expected costs to the broker.

Many different circumstances made the junk bond market of the 1980s uniquely manipulable. Drexel and the Milken partnerships were able to capture a significant share of the wedge between the demand curve and supply curve for junk bonds, as earlier illustrated by the Storer deal. Milken and Drexel were not just charging a routine commission. In many cases, they were able take advantage of an unusually large bid-ask spread and to adjust it to extract the maximum possible amount. Accordingly, they could have captured an unusually large share of the increased value of the newly issued bonds that would be caused by manipulation of default rates. So the benefits of such a manipulation would have been unusually large.

Would the costs to the broker of such a manipulation have been low enough to make it worth attempting? Certainly the costs of the manipulation would have been low indeed-zero in fact-if the refinanced issues were not financed by the broker himself, but instead were purchased by S\&Ls that were engaged in looting. The high nominal yields of the refinancings would enhance the profit statements of the S\&Ls. Additionally the owners and porfolio managers could benefit from favorable terms in the purchase of stock options or shares of Milken's partnerships.

In addition to being able to use other people's money, three additional factors amplified the effectiveness of any portfolio purchases by the S\&Ls in reducing the overall default rate. As already discussed, the high-yield securitized debt market was new and growing very rapidly (much faster than the rate of interest during the 1980s), so the volume of old issues whose default losses needed to be manipulated was quite small relative to the volume of newly issued bonds. Second, S\&L assets did not need to be used directly to purchase refinancings. It was sufficient for sophisticated investors to understand that the assets of the S\&Ls could later be used as a guarantee against future losses. In the meantime, these investors could fearlessly pocket the high coupons paid. Third, because the refinancings sold without difficulty and their premiums were so high, copycat investors (that is, investors who in- 
ferred asset quality from price) would take a significant fraction of the issues. As in the earlier example of Dallas real estate, copycat investors would multiply the impact of S\&L looting.

In sum, the junk bond market of the 1980s provided a unique opportunity for market manipulation. Were these opportunities taken? In the following discussion, we will show that the behavior of the junk bond market is in fact consistent with market manipulation.

\section{The Evidence: Actual Default Rates}

We present two kinds of evidence to support the possibility that the kind of manipulation described earlier took place during the 1980s. First, we show that even though Drexel was believed to have very low default rates, below those of other issuers, ${ }^{73}$ in fact the true default rate on its debt was higher than that for other junk underwriters. In particular, the default rate on junk issued to refinance outstanding debt was especially high, as was its debt issued for "general corporate purposes." The next section will also review evidence that Milken and his associates engaged in patterns of trading with thrifts consistent with the scheme outlined above.

Paul Asquith, David W. Mullins, and Eric D. Wolff have shown the importance of exchanges in reducing recorded default rates. ${ }^{74}$ Of the $\$ 14.6$ billion of junk bonds issued between 1977 and 1983, $\$ 2.2$ billion or about 15 percent had already been exchanged by the end of $1988 .{ }^{75}$ If these exchanges involved troubled companies that would otherwise have defaulted, the omission of these exchanges from cumulative measured defaults could have substantially altered the observed default rate. There is evidence that these issues did indeed involve unusually troubled companies because refinancings in their short average life up to the end of 1986 had a remarkably high rate of default-39 percent (by quantity) and 33 percent (by value).$^{76}$ Because the study by Asquith, Mullins, and Wolff, which is our source for these numbers, was the first

73. See George Gilder, “The War Against Wealth," Wall Street Journal, September 27, 1990, p. A12.

74. Asquith, Mullins, and Wolff (1989).

75. Authors' calculations from Asquith, Mullins, and Wolff (1989, table 1, p. 928, and table 6, p. 934).

76. Asquith, Mullins, and Wolff (1989, table 7, p. 935). 
to calculate default rates inclusive of these exchanges, there is every reason to believe that they were not taken into account in the junk bond market's halcyon years. Moreover, because this study measured default rates only up to the end of 1988 , before the collapse of the junk bond market in 1989 and 1990, the measured default rate as of this point can only underestimate the ultimate default rate.

It should be emphasized that exchanges represented only one way in which defaults could be swept under the carpet. The proceeds from issues for general corporate purposes or perhaps even for mergers and acquisitions could also be used to finance current debt service, thereby preventing default on prior issues.

A more recent analysis by the Bond Investor's Association, which makes use of a comprehensive tabulation of all junk debt, demonstrates an especially high default rate on Drexel-issued refinancings and classifies them according to the stated purpose of the debt issue. ${ }^{77}$ As of the end of 1992, the default rate on Drexel bonds issued between 1983 and 1990 to refinance existing bonds was 45.2 percent, compared with 26.0 percent for all other issuers. ${ }^{78}$ As the study's author observes, "These figures lend support to critics who have contended that Drexel concealed the poor quality of many of its issues by refinancings." 79

The chronology of events is also consistent with the hypothesis of manipulation. The collapse of the junk bond market quickly followed Milken's indictment in March 1989. Between the end of 1988 and October 1989 , the spread between the junk bond yield and the yield on ten-year Treasuries rose from 488 basis points to 704 . In 1990, the spread rose further, to above $1000 .^{80}$ (It has subsequently declined.) These changes in spread are thus much more than the 2 to 3 percent change in yield that might be thought sufficient to make possible a large takeover wave.

Furthermore, over this same period junk bond defaults rose dramatically, by one account from $\$ 5$ billion in 1988 to $\$ 22$ billion in 1990. In the first quarter of 1991 , they totaled $\$ 8.2$ billion, compared to only $\$ 1.3$ billion for the same period in $1988 .^{81}$

77. See Lehmann (1993).

78. Default rates are here calculated by averaging over issues. There were eighty-four refinancings by Drexel and one hundred by other underwriters.

79. Lehmann (1993, p. 25).

80. See First Boston Corporation (1989, 1990), quoted in Black (1993a).

81. See David Gillen, "Moody's Says Junk Quality Still Sliding; Number of Corporate Defaults Surges," The Bond Buyer, March 15, 1991, p. 3, and Constance Mitchell and 


\section{Links to Thrifts}

Although, as mentioned earlier, S\&Ls held only $\$ 13.2$ billion of junk bonds, these holdings were remarkable for their concentration: 69 percent were held by just eleven institutions, all of which had close ties to Milken. The complaint by the FDIC against Milken on behalf of the Resolution Trust Corporation (RTC) for improprieties in the junk bond market (which was settled for $\$ 1.3$ billion) ${ }^{82}$ makes the general claim that he led a group of "conspirators" (the so-called Milken Group) who used S\&L assets to raise artificially the price of junk bonds.

Beginning at least in 1982, the Milken Group and those acting in concert and conspiracy with it have willfully, deliberately and systematically plundered certain S\&Ls. The Milken Group targeted the S\&Ls because their deposits provided the S\&Ls with an enormous pool of capital. Ready, repeated, easy access to that pool of capital was a necessary part of the Milken Group's scheme to unlawfully inflate the value of junk bonds and to create the illusion that such inflated value could be realized in a liquid market. ${ }^{83}$

Again, lest there be any doubt about its claims, the complaint later reemphasizes them:

Because of the purchases by the Partnership Class [mainly partnerships owned or controlled by the Milken Group] and the other insider accounts, the Milken Group was able to create a false appearance of heavy demand for Drexel-underwritten issues. This deception furthered the scheme by giving apparent credence to the proclamations about the value of junk bonds, and the artificial demand caused the market price for such bonds to increase, enabling the Partnership Class and other insider accounts to reap substantial profits and thus to reward various participants in their schemes. ${ }^{84}$

According to the complaint, many $S \& L$ executives variously mismanaged their junk bond purchases. Three of these-Thomas Spiegel of Columbia, Charles Keating of Lincoln, and David Paul of CenTrustwere, along with unknown others, named as co-defendants. According to James B. Stewart, Columbia S\&L was one of the "captive" institutions that allowed Milken to "freely trade" in their accounts ${ }^{85}$ Columbia

Anita Raghaven, "Junk Bond Prices Hold Steady Despite Report That Defaults Hit a Record in the Latest Period," Wall Street Journal, April 9, 1991, p. 50, quoted in Black (1993b).

82. See Stewart (1992, p. 523) and Seidman (1993, p. 238).

83. FDIC v. Milken (1991, p. 38).

84. FDIC v. Milken (1991, pp. 44-45).

85. Stewart (1992, p. 521). 
was the largest holder of junk bonds by a factor of two, with more than a quarter of all S\&L-held junk. Benjamin J. Stein has described how Spiegel was partially rewarded for such cooperation. ${ }^{86}$ Stein reports a transaction between Milken and Spiegel involving Columbia's purchase of the shaky bonds and preferred stocks involved in the Storer Communications leveraged buyout described above. A partnership owned by Spiegel family members was reportedly given stock options for equity in Storer for $\$ 132,000$, with the options sold about a year after the leveraged buyout for $\$ 7$ million. ${ }^{87}$

The complaint claims that such behavior was part of a general pattern:

The Milken Group cultivated a group of persons who controlled S\&Ls. Each of these persons purchased and sold junk bonds at the bidding of the Milken Group. Each of these persons intended to share in the plunder of their respective institutions and to obtain other benefits the Milken Group provided to those who purchased large quantities of Drexel-underwritten junk bonds. These persons, although not necessarily aware of the scope of or participating in the broad range of illegal activity engaged in by the Milken Group, agreed to follow the bidding of the Milken Group for their own benefit and contrary to the interests of their respective institutions. The persons, in addition to others not now known, include Charles H. Keating, Jr., who controlled Lincoln, David Paul, who controlled CenTrust, and Thomas Spiegel, who controlled Columbia. ${ }^{88}$

According to other sources, such use of other people's money was not confined to S\&Ls. According to Stewart and Stein, Fred Carr, the head of First Executive Life Insurance, also gave control of his junk bond portfolio over to Milken. Carr let Milken's group trade the bonds in the First Executive portfolio and send the tickets for confirmation later. ${ }^{89}$ The details in this case are relatively well established since the First Executive Companies (the parent), which had presumed assets of $\$ 15.2$ billion, became massively insolvent and was taken over by authorities in 1991. Roughly one-third of the assets in the life insurance company were invested in junk bonds. By comparison, Metropolitan Life had 1 percent of its portfolio in junk, Aetna had 1 percent, and Prudential, 3 percent. ${ }^{90}$

86. Stein (1992).

87. Stein (1992, p. 105).

88. FDIC v. Milken (1991, p. 32).

89. See Stewart (1992, p. 521) and Stein (1992).

90. A.M. Best Company (1990). 
Milken and Drexel took an active part, apparently, in the transfer of ownership of many of the S\&Ls that the complaint describes as captives. In some cases, the connection was indirect, made through close associates. According to the complaint, for example, Executive Life financed the acquisition of 24.9 percent of the equity of Imperial Savings and Loan, while subsidiaries of Columbia took over 8.1 percent of Imperial's common stock. ${ }^{91}$ But the relationship was often direct. In the case of Columbia, for example, Drexel acquired 10.3 percent, and a trust for Milken's children acquired 9.9 percent of the S\&L's common stockshares that were sold after Columbia acquired a significant junk bond portfolio. ${ }^{92}$ Milken also financed the acquisition of Lincoln Savings and Loan by Charles Keating; Ivan Boesky has testified that Milken repeatedly encouraged him to purchase a thrift.

Finally, there is circumstantial evidence that members of the Milken group also tried to manipulate junk bond ratings. According to Stein, the bond rating company Duff \& Phelps was taken over by a partnership that had undisclosed ownership shares held by members of the Milken group, including James Dahl, Milken's top salesman in the Beverly Hills office, as well as two of the "captive" thrifts named in the complaint, Imperial and Columbia. Duff \& Phelps subsequently gave favorable ratings to bonds that were issued by Columbia. ${ }^{93}$

\section{Calibrating the Magnitudes}

Institutions with close links to Milken and Drexel controlled portfolios that held about $\$ 14$ billion in junk bonds: about $\$ 9$ billion at the thrifts named as captives in the complaint and about $\$ 5$ billion at First Executive. Total defaults on all original issue high-yield bonds with issue dates of 1986 or earlier totaled only $\$ 7.6$ billion until the end of $1988 . .^{94}$ If one-quarter of the junk holdings of the so-called "captive" institutions were used to prevent defaults, this by itself would have reduced the observed default rate by about one-third. If Milken could have persuaded others to purchase some of the bonds of troubled companies, the reduction in the observed default rate would have been greater. One

91. FDIC v. Milken (1991, p. 62).

92. FDIC v. Milken (1991, p. 56).

93. Stein (1992, pp. 147-48).

94. See Asquith, Mullins, and Wolff (1989, table iv, p. 932). 
potential source of purchasers was insiders with implicit guarantees that the captives would purchase the bonds before prices fell. Outside investors, behaving like the copycats in Dallas or index investors in the stock market, may also have bought some of these troubled bonds because apparently sophisticated investors were also buying them. Thus junk bond portfolios of the S\&Ls were of sufficient size to have had significant impact on perceived default rates in this market.

One more simple calculation suggests how profitable the link with a savings and loan could be. Drexel underwrote the acquisition of Lincoln S\&L by Charles Keating's takeover vehicle, American Continental Corporation (ACC), at a cost of $\$ 56$ million. Over the next five years, Lincoln purchased $\$ 2.7$ billion of junk bonds. ${ }^{95}$ It is easy to verify, with the annual pattern of junk bond purchases reported in the FDIC complaint, that even if Drexel charged at the lower end of its commissions ( 3 percent) and even if it had a discount rate as high as 15 percent, the commission income alone would have more than paid for the entire purchase price of the thrift-even if Drexel had given the entire $\$ 56$ million to Keating.

\section{The Role of Manipulation in the Takeover Wave}

Whatever the evidence for manipulation of the junk bond market of the 1980s, such manipulation cannot be the whole explanation for the takeover wave of the 1980s. The gain to shareholders of acquired firms between 1977 and 1986 was $\$ 346$ billion in 1986 dollars. ${ }^{96}$ Because this increase is much larger than the total volume of junk bonds, no amount of manipulation could have transferred such a sum from holders of junk bonds to shareholders. Thus the manipulation of default rates can, at best, be only a partial explanation for the 1980s takeover wave. Evidence of other transfers (which shows that they also tended to be small relative to total shareholder gains), has been given by Jeffrey Pontiff, Andrei Shleifer, and Michael S. Weisbach on losses to previous bondholders, Sanjai Bhagat, Andrei Shleifer, and Robert W. Vishny on tax benefits and layoffs, and Alan J. Auerbach and David Reishus on tax benefits. ${ }^{97}$ Thus stocks must have been undervalued relative to funda-

95. FDIC v. Milken (1991, p. 64).

96. Jensen (1988, p. 21).

97. Pontiff, Shleifer, and Weisbach (1990); Bhagat, Shleifer, and Vishny (1990); and Auerbach and Reishus (1988). 
mentals prior to the $1980 \mathrm{~s}$, or overvalued thereafter. A full explanation of the takeover wave, irrespective of the role of manipulation of the junk bond market, must explain this departure from fundamental values, which made the takeovers so profitable.

\section{Conclusion}

This paper has shown how other people's money, typically deposits in financial institutions or insurance funds, can profitably be looted, with the guarantor of the assets, typically the government and its taxpayers, left holding the bag. These opportunities for looting occur when the value of the take net of the cost of prosecution, $M^{*}$, exceeds the expected value of the underlying institution, $V^{*}$. Under such circumstances, there is special reason for owners of the financial institution to make shady deals with those who make large (perhaps under-the-table) current payments and unkeepable future promises. The large current payments will increase $M^{*}$. The unkeepable promises will decrease the value of the institution below $V^{*}$.

Furthermore, initial disturbances caused by looting in one market are likely to metastasize with serious multiplier effects into other markets. Thus the looting of S\&Ls may result in a construction, or a corporate leveraged buyout, boom and bust. Large multiplier effects are caused by buyers (or sellers) who watch standard signals of market activity to determine their behavior, but who fail to understand that the usual behavior of their signals has been altered by unsuspected looting. The multiplier effects are likely to be particularly large if the actions of the looters can be coordinated in a way that is designed to manipulate market signals.

We examined four historical events in light of our model: the Chilean financial crisis, U.S. S\&L regulatory changes, the Dallas/Fort Worth building boom and bust, and the junk bond-financed takeover wave. These illustrations show not only how the looters themselves behave, but also how they interact symbiotically with their accomplices and react to the attempts by the regulators to stop their activities. The historical instances also show, as the theory would predict, that the exact outcome in this game of cat (the regulators) and mouse (the looters) depends very specifically on the constraints faced by the cat and, sometimes, also on its errors. 
The theory of looting gives an historical interpretation of what went wrong in the 1980s, and points to other areas that could emerge in the future. Insurance companies, especially life insurance companies, are prime targets for looting. The bankruptcy of First Executive Life showed how a life insurance company could be looted through excessive purchase of junk bonds. The case of Coastal States Life Insurance of Georgia, seized in December 1992, shows the difficulty regulators have in controlling portfolios with complicated securities that they do not know how to value..$^{98}$ Coastal put almost all of its portfolio into interestonly strips of collateralized mortgage obligations and inverse floaters. After the market value on this supposedly hedged portfolio plunged, it took two years to close Coastal because the owner claimed to have broken no rules. However large the losses to policy holders or the people who will be taxed to make up the losses, Coastal States' owner did not do badly. His life insurance company gave the marketing affiliate he owned $\$ 15.5$ million of contracts during the few short years of its life. Given the relatively loose structure of insurance supervision, what happened at Coastal can happen at many other insurance firms.

The possibilities to loot pension funds are analogous to the possibilities to loot life insurance companies. Furthermore, where there are pension guarantees, the taxpayers are the ultimate bearers of the burden of underfunded pensions when the sponsor firms go bankrupt. TWA is a case in point. Although its pension fund was one of the country's most underfunded, it offered its workers benefit increases of $\$ 100$ million while it was in bankruptcy. ${ }^{99}$ To avoid such moral hazard, bills have been introduced (but not passed) in Congress to prevent the most underfunded pension plans from increasing pension benefits. ${ }^{100}$ One estimate of the uncovered liabilities of the federal government's Pension Benefit Guaranty Corporation is $\$ 35$ billion. ${ }^{101}$

The currently unfolding scandal on mortgage guarantees backed by the U.S. Department of Housing and Urban Development (HUD) gives a sense of déjà vu because the major features of the $S \& L$ scandal are repeated in a new context. The government, for example, is now respon-

98. See Laura Jereski, "Seized Insurer's Woes Reflect Perils of CMOs," Wall Street Journal, May 12, 1993, p. C1.

99. See U.S. Congressional Budget Office (1993, p. 12).

100. U.S. Congressional Budget Office (1993, p. 29).

101. See U.S. Congressional Budget Office (1993, p. 3). 
sible for the $\$ 9.5$ million mortgage on a property in Boston, where "unnecessary costs" were incurred. The board in charge, it was concluded, had "not always act[ed] in the best interests of the project." ${ }^{102}$ Some $\$ 43$ billion of such mortgage guarantees have been issued, with defaults expected on $\$ 11.9$ billion. ${ }^{103}$

Finally, banking crises are endemic to high-inflation countries. In the 1980s, bank stringency occurred in Argentina, Brazil, Chile, Colombia, Costa Rica, Ecuador, Mexico, Peru, and Venezuela, as well as other countries. ${ }^{104}$ This paper has shown how attempts to curb the inflation of Latin America can lead to the looting of banks if currency convertibility is one aspect of the disinflation program. Such currency convertibility is now standard advice to countries fighting inflation. ${ }^{105}$ The theory and examples of this paper warn that the maintenance of such convertibility must be accompanied by careful bank regulation to prevent looting of the kind that occurred in Chile. More generally, it is a safe bet that many developing countries that have far less sophisticated and honest regulatory mechanisms than those that exist in the United States will be victimized by financial market fraud as their financial markets develop.

The S\&L fiasco in the United States leaves us with the question, why did the government leave itself so exposed to abuse? Part of the answer, of course, is that actions taken by the government are the result of the political process. When regulators hid the extent of the true problem with artificial accounting devices, when congressmen pressured regulators to go easy on favored constituents and political donors, when the largest brokerage firms lobbied to protect their ability to funnel brokered deposits to any thrift in the country, when the lobbyists for the savings and loan industry adopted the strategy of postponing action until industry difficulties were so large that general tax revenue would have to be used to address problems instead of revenue raised from taxes on successful firms in the industry-when these and many other actions were taken, people responded rationally to the incentives they faced within the political process.

102. See Jason DeParle, "Housing Project Haunted by Ghosts of Noble Ideals," New York Times, September 18, 1993, p. A8.

103. Price Waterhouse and Company estimate cited in the Wall Street Journal, June 21, 1993, p. A12.

104. See Brock (1992, p. 1).

105. See Sachs and Larrain (1992, pp. 746-47). 
The S\&L crisis, however, was also caused by misunderstanding. Neither the public nor economists foresaw that the regulations of the 1980s were bound to produce looting. Nor, unaware of the concept, could they have known how serious it would be. Thus the regulators in the field who understood what was happening from the beginning found lukewarm support, at best, for their cause. Now we know better. If we learn from experience, history need not repeat itself. 


\section{Comments and Discussion}

Robert E. Hall: George Akerlof and Paul Romer challenge the universal earlier view that the harm from deposit insurance and other loan guarantees comes from its truncation of the lower tail of the distribution of payoffs. Under that view, guarantees would be harmless in a nonstochastic world. The alternative, put forward with vigor and success in this paper, is that asymmetric payoffs_-"fourth-quarter football"-have little to do with the actual costs of episodes like the S\&L debacle. Rather, guarantees create opportunities for profits from looting that exist independently of any random outcomes. Although the paper mentions looting strategies that may be legal, most of the actual conduct it describes is illegal and most of the players have been prosecuted. Policy appears to have been more successful in closing the legal loopholes than in preventing illegal behavior before it became extremely costly.

As of the early 1980s, the legal strategy for exploiting deposit insurance was to make high-interest loans, buy junk bonds, or purchase an S\&L under terms with significant accounting goodwill, and then pay bloated salaries and dividends from the false accounting income these investments generated. This approach would have yielded a few million dollars per S\&L; anything larger would have attracted the attention of regulators, who understood the temptation to pay excess dividends and salaries.

In addition to exaggerated dividends and salaries, the paper describes three other methods of value extraction that appear to transcend legality: concessionary loans to owners; loans to straws, who then share the proceeds with the owners; and asset purchases or exchanges at exaggerated prices involving owners.

Although the incentive to loot comes from the ability to extract value from an S\&L, the paper devotes much more attention to the income- 
exaggerating strategies of the big players in the 1980s and surprisingly little to the value-extraction part of the story. For Chile, there is only one paragraph explaining that the owners of government-guaranteed banks did not capture any significant looting proceeds themselves, but that lending to affiliates at preferential rates did extract some value. Since such lending reduced the book earnings that drove looting in the first place, the story seems incomplete. The focus on income exaggeration rather than value extraction in the discussion of U.S. S\&Ls is just as strong. The authors write, "To establish a case for looting, it is necessary to show that loans were made, or assets purchased, in circumstances in which no reasonable person could expect a future positive payoff in any future state of the world, but for which the present payoff was very high." No mention is made here of value extraction. The colorful account of the history of Empire Savings and Loan says not a word about whether the owners received anything for their efforts. The reader is invited to infer that nobody would have done the crazy things that happened at S\&Ls unless they planned to take a lot of money out, but the paper gives no evidence to support that inference. We could just as well conclude that S\&L managers got caught up in a frenzy of bad lending and bad deals from which they gained little. We do not even know if the developers who collaborated in the process by pursuing bad projects gained much. We do know that the debacle had huge social costs.

The paper builds a case that looting, rather than incompetence or fourth-quarter football, accounted for a large fraction of deposit insurance payouts. One piece of evidence is that the payouts for S\&Ls where the government has prosecuted looters have totaled about $\$ 54$ billion. The paper does not give any figure on a comparable basis for total resolution costs, so we do not have a good way to determine whether $\$ 54$ billion is a large fraction or not.

A second piece of evidence that Akerlof and Romer offer for the importance of looting is the favorable performance of savings banks, subject to tight regulation as banks, in comparison to the loosely regulated S\&Ls. Total resolution costs for the savings banks have been only about $\$ 7$ billion. Had the $S \& L s$ had the same resolution cost per dollar of assets, total resolution costs for the industry would have been only $\$ 28$ billion. Again, no comparable actual figure is available for comparison, but the actual total is many times higher. But this evidence is completely consistent with, say, the hypothesis of managerial incompetence. By al- 
most any theory of S\&L misbehavior, looting or otherwise, tighter regulation would reduce resolution costs. A reasonable view of the difference between S\&Ls and savings banks is that it reflects all the dangers of handing one's Visa card to a stranger and not monitoring its use very carefully - the approach the FSLIC took to deposit insurance. Looting is one of the dangers, but carelessness is another.

The third piece of evidence is the lower incidence of failure at mutual thrifts in comparison to stock thrifts. The ratio is a little over three to one. I think this evidence points more clearly to looting; both types of institutions are the responsibility of the same regulators. But it is a little troubling that more than 8 percent of mutuals failed, even though their structure effectively bars most forms of looting.

The paper argues that the social costs of looting are greater than just the federal bailout costs; there are multiplier effects from the guaranteed institutions to the broader economy. The first example of a multiplier effect arises in their model of the Dallas real estate market. The formal model is a cousin of Robert Lucas's famous monetary nonneutrality model. ${ }^{1}$ But Akerlof and Romer get a bigger effect because the intrusion of looters in their model is an unprecedented event, whereas in Lucas's model, rational actors are aware that unusual things may happen and wisely limit their response to conditions that may be created by those events.

Lucas's model loses its multiplier property if anybody reads the Wall Street Journal, and, similarly, Akerlof and Romer's model falls apart if lenders and developers read the National Real Estate Investor News. The model rests on incredible naïveté among the honest players in the market. I do not think there is any question that real estate development overshot in Dallas in the 1980s. Part of the overshooting, of course, is explained by the direct effects of S\&L lending generosity. Whether a multiplier model is needed to understand the rest is an interesting question not fully answered by this paper.

The second multiplier model deals with manipulation of the junk bond market. The discussion here raises the possibility that looters at S\&Ls helped defer default and reduce observed default rates. In this way, they contributed to what appears to have been a massive overvaluation of junk bonds. Although colorful, the discussion left me feeling that the ar-

1. Lucas (1972). 
gument was a stretch. There is no discussion of any social costs of the overvaluation, another subtle issue that would have to be developed as part of a convincing argument that there were large adverse multiplier effects on social welfare from looting.

In spite of my misgivings about the persuasive power of the evidence, especially about multiplier effects, I think the paper does a great service by identifying clearly what is probably the leading danger of the growing tendency of the federal government to open its checkbook to outsiders. The danger is absolutely direct; people will figure out ways to write themselves large checks, and they will risk jail if the checks are large enough. Economists' views about the hazards of loan guarantees have not been realistic about human nature.

The paper mentions briefly some of the other loan guarantee programs where looting is prevalent. In fact, the brief account of events at Coastal States Life Insurance is one of the cleanest examples of looting. Federal guarantees of pension benefits offer another example of looting within the paradigm of the paper. The Clinton administration has talked about a new type of pension fund guarantee for "social" investments that appears particularly ripe for looting. Although federal guarantees of single-family mortgages seems to have escaped looting so far, it appears that other mortgage guarantee programs are being looted. Federal student loan programs have been looted extensively, though not by the methods described in the paper. In all instances, tight, vigilant regulation can block looting, but regulators do not always perform to that standard.

Richard Posner has made the profound argument that any government benefit program induces social rent-seeking losses equal to the private benefits conferred. The whole idea of benefits is fundamentally perverse, in that view. Akerlof and Romer go even further to show that social losses are many times the private benefits when the benefits must be earned by looting.

N. Gregory Mankiw: According to a view now popular in the media, the 1980s were a decade of unusual, unmitigated greed. The ultimate symbol of this greed was the savings and loan crisis. The root cause, according to the conventional wisdom, was the laissez-faire policies of the Reagan administration. 
Although the two authors from Berkeley did not intend this paper to be a defense of Ronald Reagan and his view of government, one can easily interpret it this way. The paper shows that the savings and loan crisis was the result not of unregulated markets, but of overregulated ones (or, at least, poorly regulated ones). After reading the paper, one is left with the impression that the policy mistakes that happened here are probably not isolated, and that the only good solution is to get the government out of this kind of business altogether.

The policy that led to the savings and loan crisis is, according to these authors, deposit insurance. This conclusion is not new, of course. What is new here is the discussion of the mechanism through which deposit insurance caused the problem. The standard story is that deposit insurance, together with low levels of capitalization, induced savings and loans to take excessive risks. This behavior is sometimes called "gambling for resurrection." By contrast, George Akerlof and Paul Romer suggest a more direct mechanism for how a savings and loan might take advantage of deposit insurance. The owners can simply take in deposits, pay themselves dividends greater than the net worth of the business, and then leave the government to pay off the resulting debts. Akerlof and Romer call this behavior "looting."

The paper offers many fascinating anecdotes suggesting that looting was part of the story behind the perverse business practices of the savings and loans. Indeed, given the incentives that regulators set up, it would be irrational for operators of the savings and loans not to loot. A key question is whether looting or gambling for resurrection was the root cause of the savings and loan problem. Here the paper falls a bit short. I am not yet persuaded that looting was the primary motive.

One problem in interpreting the many shreds of evidence in the paper is that looting and gambling for resurrection are not really alternative strategies. Indeed, they are highly complementary. Consider an owner of a savings and loan who is taking excessive risks, hoping that they pay off and make him rich. It is only prudent for him to loot as much as he can, because he knows that his gambles might not pay off.

If looting is the primary motive, rather than just a rational subsidiary strategy, running a savings and loan must have been profitable even if default occurs. That is, the owners of failed savings and loans should now be living happily ever after. The paper does not convince me that 
this is true. Undoubtedly, it is hard to tell, in part because successful looters are loathe to advertise their good fortune.

According to Akerlof and Romer, looting rather than gambling must have been the primary motive, because many of the loans made were so bad there was no reasonable hope of them paying off. Again, I am not persuaded. First, it is not surprising that the operators of savings and loans were bad businessmen. Gambling for resurrection is not a business strategy that is likely to attract the best and the brightest of the financial community.

Second, in the presence of adverse shocks, it is hard to tell an excessively risky gamble from a completely hopeless one. Consider, for example, what would have happened if the price of oil had doubled in 1986, rather than halving as it did. Clearly, the history of Texas real estate would have looked very different. Most likely, the owners of the Texas savings and loans would today be treated as prescient heros rather than despicable scoundrels. The media would praise them for their far-sightedness, and they would now be in the pantheon of financial greats with Warren Buffet and George Soros. In reality, the collapse in world oil prices was part of the story behind the Texas savings and loans. It is hard to know for sure what would have happened if the shocks had been more favorable.

Let me now turn to what this episode implies for public policy. A common reaction to the savings and loan crisis is that it shows the need for higher capital requirements, better accounting rules, and more vigilant regulators. In contrast, I view the message as being more basic. This episode calls into question the desirability of government insurance for bank deposits, as well as the entire banking system on which our economy relies.

Traditional banks are peculiar institutions. Traditional banks have depositors who want short-term, liquid, riskless assets. Yet these deposits are backed by long-term, illiquid, risky loans. This incongruity is fundamental. As we have seen, it cannot be easily fixed by a government policy such as deposit insurance.

There is, however, a simple, market-based solution: mutual funds. Individuals who want truly riskless assets can invest in mutual funds that hold only Treasury bills. Those who are willing to undertake greater risk can invest in mutual funds that hold privately issued CDs, bonds, or equities. Long-term, illiquid loans could be made by finance companies, 
which would raise funds by issuing equity and bonds. In the world I am describing, all household assets would be perfectly liquid. Preventing bank runs-the original motivation for deposit insurance-would be unnecessary, because changes in demand for various assets would be reflected in market prices.

In essence, the system we have now is one in which finance companies are themselves financed with demand deposits. Yet these finance companies hold assets-long-term bank loans-that are risky and illiquid, much in the same way that fixed capital is risky and liquid. Imagine that the auto industry financed itself with demand deposits. Undoubtedly, self-fulfilling "runs" on GM and Ford would be common, and the auto industry would be highly unstable. Indeed, the auto industry would probably be a major source of macroeconomic instability. The best solution, of course, would not be deposit insurance and regulation of the auto industry, but a change in the way the industry financed itself.

There is also a more general lesson to be learned from the savings and loan crisis. When I was a student in the 1970 s, I was taught that deposit insurance is an almost perfect government policy. The policy assures depositors that their money is safe. At the same time, it establishes a good equilibrium without bank runs and bank failures, so the policy costs the government almost nothing.

So much for theory. The general lesson from this experience is one that Ronald Reagan would embrace: government intervention into private markets is usually more expensive and has more perverse incentive effects than one can anticipate. This lesson is a timely one, because the current administration looks like it may turn out to be the most activist in twenty-five years.

\section{General Discussion}

William Black offered three specific reasons why people engaged in illegal looting when they could have looted legally. First, the amount of loot is limited if one sticks to dividends or salaries. Second, looting with excessive dividends and salaries was too obvious, and would have attracted attention from regulators. Finally, there were big gains to staying in business as long as possible in order to extract more loot, which led 
institutions to make additional illegal loans to keep old ones from going into default.

James Tobin agreed that Greg Mankiw's proposal for a depository institution backed by treasuries would provide a safe medium of exchange, while avoiding the potential problems of deposit insurance when banks hold a risky portfolio. He noted the similarity to "corebanking" proposals made in the past, and suggested that safe-asset banking could be done either by the government or within existing banks. Chris Sims observed that Mankiw's proposed risk-free mutual funds either do not represent complete deregulation or are not risk-free; if there were not publicly enforced restrictions on the assets held by the funds, there would be a risk to depositors that the funds would undertake risky investments. Romer pointed out that Mankiw's proposal deals only with bank deposit insurance and provides no solution for other situations where the government gives guarantees, including insurance, pensions, and student loans.

Mankiw's comments that the S\&L crisis is an example of excessive government regulation generated a lively discussion. Chris Sims argued that Mankiw turned the matter on its head because the defining feature of the 1980s was deregulation, not regulation. He added that it is simplistic to believe that shrinking the government will solve every problem; criminals are always in favor of shrinking government-particularly the part that polices them-and will of course take advantage of opportunities to pass themselves off as part of a crowd interested in efficiency.

Black pursued the issue of what caused the regulatory breakdown in the 1980s and why it occurred primarily at the Federal Savings and Loan Insurance Corporation (FSLIC). He suggested that moral hazard at the FSLIC played an important role; it was already insolvent and therefore the people in charge had a strong incentive to take excessive risks. More generally, the Reagan-Bush administrations maintained a strong antiregulatory stance; it was official administration policy not to close insolvent institutions unless they had a severe liquidity crisis, which could be avoided for a long time with deposit insurance. Black also pointed to the legislation that allowed thrifts to diversify into new assets. Because the new class of assets did not have readily ascertainable market values, they were well suited to engaging in fraudulent behavior that could be hidden with "accounting gamesmanship." 
In the same vein, Tobin recalled the reply that William Seidman of the FDIC received when he asked the White House for more regulators: "Perhaps you don't understand what administration you are working for." Tobin also pointed to the increased limit on insured deposits to $\$ 100,000$ as a cause of the regulatory breakdown. But Romer suggested that if the limit had been lower, people would simply have split up their funds among different institutions. In contrast to the conclusion reached by Mankiw, the lesson Tobin drew from the S\&L debacle was that deregulation cannot be done piecemeal; if the government is going to deregulate the asset side of the balance sheet and ease up on regulatory oversight, it has to give up on deposit insurance at the same time.

William Nordhaus proposed additional reasons why deposit insurance did not have harmful effects until the 1980s. One possibility is that looting just was not accepted until the 1980s; fads, epidemics, and fashions have important sway in determining moral and economic behavior. Another possibility is that "depressions uncover what the accountants miss," and that looting-type behavior was widespread but not discovered until the depression in real estate. Nordhaus concluded by noting that roughly two generations elapse between debt crises, raising the possibility that the country would be due for another in about sixty years.

Barry Eichengreen brought up additional examples where the authors' model could be applied. In Germany, people are forced to insure their low-quality Trabant cars for more than they are worth. So people actually invite their cars to be stolen-by leaving their doors unlocked and the keys in the ignition, for example. Looting, also known as "spontaneous privatization," is encouraged in Russia by soft budget constraints that prevent the firms in which the "looters" are employed from suffering the consequences. In the nineteenth century, Eichengreen added, government guarantees of railroad bonds led to sweetheart deals between promoters of railroads and construction companies in Canada, India, Australia, and Africa, which were probably responsible for the widespread failures of railroad enterprises. Fewer failures occured in the United States, where bond guarantees were less prevalent. 


\section{References}

Adams, James R. 1990. The Big Fix: Inside the S\&L Scandal. New York: John Wiley.

A.M. Best Company. 1990. Best's Insurance Reports: Life-Health. Oldwick, N.J.: A.M. Best.

Asquith, Paul, David W. Mullins, Jr., and Eric D. Wolff. 1989. "Original Issue High Yield Bonds: Aging Analyses of Defaults, Exchanges and Calls." Journal of Finance 44(4):923-52.

Asquith, Paul, and Thierry A. Wizman. 1990. "Event Risk, Covenants and Bondholder Returns in Leveraged Buyouts." Journal of Financial Economics 27:195-213.

Auerbach, Alan J., and David Reishus. 1988. "Taxes and the Merger Decision." In Knights, Raiders, and Targets: The Impact of the Hostile Takeover, edited by John C. Coffee, Jr., Louis Lowenstein, and Susan Rose-Ackerman. New York: Oxford University Press.

Banerjee, Abhijit V. 1993. “A Simple Model of Herd Behavior." Quarterly Journal of Economics (forthcoming).

Barth, James R. 1991. The Great Savings and Loan Debacle. Washington: AEI Press.

Bhagat, Sanjai, Andrei Shleifer, and Robert W. Vishny. 1990. "Hostile Takeovers in the 1980s: The Return to Corporate Specialization." BPEA, Microeconomics, 1992:1-72.

Bikhchandani, Sushil, David Hirshleifer, and Ivo Welch. 1992. "A Theory of Fads, Fashion, Custom and Cultural Change as Informational Cascades." Journal of Political Economy 100(5):992-1026.

Black, William K. 1990. "Ending Our Forebearers' Forbearances: FIRREA and Supervisory Goodwill." Stanford Law and Policy Review 2(1):102-16.

—. 1993a. "Junk Bonds." Staff Report 7. San Francisco: National Commission on Financial Institution Reform, Recovery, and Enforcement (April 8).

- 1993b. "The Incidence and Cost of Fraud and Insider Abuse." Staff report 13. San Francisco: National Commission on Financial Institution Reform, Recovery, and Enforcement (April 12).

Brealey, Richard, and Stewart Myers. 1984. Principles of Corporate Finance. New York: McGraw-Hill.

Breeden, Richard C. 1990. "Concerning Issues Involving Financial Institutions and Accounting Principles Before the Committee on Banking, Housing and Urban Affairs, United States Senate." Paper prepared for the U.S. Securities and Exchange Commission for testimony before the U.S. Senate Committee on Banking, Housing, and Urban Affairs (September 10).

Brock, Philip L. 1992. "Introduction." In If Texas Were Chile: A Primer on Banking Reform, edited by Philip L. Brock. San Francisco: ICS Press.

Bruck, Connie. 1989. The Predators' Ball: The Inside Story of Drexel Burnham and the Rise of Junk Bond Raiders. New York: Penguin Books. 
Brumbaugh, R. Dan, Jr., Andrew S. Carron, and Robert E. Litan. 1989. "Cleaning Up the Depository Institutions Mess." BPEA, 1:1989, 243-83.

Burrough, Bryan, and John Helyar. 1990. Barbarians at the Gate: The Fall of RJR Nabisco. New York: Harper and Row.

Caplin, Andrew, and John Leahy. 1991. "Business as Usual, Market Crashes and Wisdom after the Fact." Unpublished paper. Columbia University and Harvard University (December).

Craine, Roger. 1992. "Fairly Priced Deposit Insurance." Unpublished paper. University of California, Berkeley (November).

de la Cuadra, Sergio, and Salvador Valdés. 1992. "Myths and Facts about Financial Liberalization in Chile: 1974-1983." In If Texas Were Chile: A Primer on Banking Reform, edited by Philip L. Brock. San Francisco: ICS Press.

Edwards, Sebastian, and Alejandro Cox Edwards. 1991. Monetarism and Liberalization: The Chilean Experiment. Chicago: University of Chicago Press.

Esty, Benjamin C. 1992. "Organizational Form, Leverage and Incentives: A Study of Risk Taking in the S\&L Industry." Harvard Business School (December 7).

First Boston Corporation. 1989. High Yield Research, 3rd Quarter Review (October).

- 1990. High Yield Research, 3rd Quarter Review (October).

Friedman, Benjamin. 1989. "Comment on 'Cleaning Up the Depository Institutions Mess." BPEA, 1:1989, 284-90.

Grossman, Sanford J. 1976. "On the Efficiency of Competitive Stock Markets Where Traders Have Diverse Information." Journal of Finance 31:573-85.

Jensen, Michael C. 1988. "Takeovers: Their Causes and Consequences." The Journal of Economic Perspectives 2(1):21-48.

Kane, Edward J. 1989. The S\&L Insurance Mess: How Did It Happen? Washington: Urban Institute Press.

Kornbluth, Jesse. 1992. Highly Confident: The Crime and Punishment of Michael Milken. New York: William Morrow.

Lehmann, Richard. 1993. "Analyzing Bond Defaults by Proceeds." Merrill Lynch: Extra Credit (January/February):24-28.

Lucas, Robert E. Jr. 1972. "Expectations and the Neutrality of Money." Journal of Economic Theory 4:103-24.

Mayer, Martin. 1990. The Greatest-Ever Bank Robbery: The Collapse of the Savings and Loan Industry. New York: Charles Scribner's Sons.

McKinnon, Ronald I. 1991. The Order of Economic Liberalization: Financial Control in the Transition to a Market Economy. Baltimore: Johns Hopkins University Press.

Merton, Robert. 1978. "On the Cost of Deposit Insurance When There Are Surveillance Costs." Journal of Business 51(3):439-52.

National Commission on Financial Institution Reform, Recovery, and Enforcement. 1993. Origins and Causes of the $S \& L$ Debacle: A Blueprint for Reform. Washington: The Commission. 
O'Shea, James. 1991. The Daisy Chain: How Borrowed Billions Sank a Texas $S \& L$. New York: Pocketbooks.

Pizzo, Stephen, Mary Fricker, and Paul Muolo. 1989. Inside Job: The Looting of America's Savings and Loans. New York: McGraw-Hill.

Pontiff, Jeffrey, Andrei Shleifer, and Michael S. Weisbach. 1990. "Reversions of Excess Pension Assets After Takeovers." Rand Journal of Economics 21:600-13.

Robinson, Michael A. 1990. Overdrawn: The Bailout of American Savings. New York: Dutton.

Romer, David. 1993. "Rational Asset Price Movements Without News." American Economic Review (forthcoming).

Sachs, Jeffrey D., and Felipe B. Larrain. 1992. Macroeconomics in the Global Economy. Englewood Cliffs, N.J.: Prentice-Hall.

Scherer, Frederic M. 1988. "Corporate Takeovers: The Efficiency Arguments." Journal of Economic Perspectives 2(1):69-82.

Seidman, William L. 1993. Full Faith and Credit: The Great S\&L Debacle and Other Washington Sagas. New York: Random House.

Shleifer, Andrei, and Robert W. Vishny. 1988. "Value Maximization and the Acquisition Process." Journal of Economic Perspectives 2(Winter):7-20.

Short, Genie D., and Jeffrey W. Gunther. "The Texas Thrift Situation: Implications for the Texas Financial Industry." Paper prepared for Financial Industry Studies Department, Federal Reserve Bank of Dallas, Dallas, Texas (September).

Stein, Benjamin J. 1992. A License to Steal: The Untold Story of Michael Milken and the Conspiracy to Bilk the Nation. New York: Simon and Schuster.

Stewart, James B. 1992. Den of Thieves. New York: Simon and Schuster.

Stiglitz, Joseph E., and Andrew Weiss. 1981. "Credit Rationing in Markets with Imperfect Information." American Economic Review 71(3):393-410.

Tybout, James. 1986. "A Firm-Level Chronicle of Financial Crises in the Southern Cone." Journal of Development Economics 24(2):371-400.

Urban Land Institute. Various years. ULI Market Profiles. Washington: ULI.

U.S. Congressional Budget Office. 1993. Controlling Losses of the Pension Benefit Guaranty Corporation. Washington: Government Printing Office.

U.S. Federal Deposit Insurance Corporation et. al. v. Michael R. Milken et. al. 1991. U.S. District Court, Southern District of New York (January 18).

U.S. House of Representatives. Subcommittee of the Committee on Government Operations. 1987. Fraud and Abuse by Insiders, Borrowers, and Appraisers in the California Thrift Industry. Hearing. 100 Cong. 1st sess. Government Printing Office.

- Committee on Banking, Finance and Urban Affairs. 1990. Effectiveness of Law Enforcement Against Financial Crime. Field hearing. 101 Cong. 2 sess. Government Printing Office. Part 1.

U.S. Senate. Committee on Banking, Housing, and Urban Affairs. 1990. Fraud in America's Insured Depository Institutions. Hearing. 101 Cong. 2 sess. Government Printing Office. 
1991. Restructuring the Resolution Trust Corporation and the Semiannual report on FIRREA Legislation:1991. Hearing. 102 Cong. 1 sess. Government Printing Office.

Velasco, Andrés. 1991. "Liberalization, Crisis, Intervention: The Chilean Financial System, 1975-85." In Banking Crises: Cases and Issues, edited by V. Sundararajan and Tomás J. T. Baliño. Washington: International Monetary Fund.

White, Lawrence J. 1991. The S\&L Debacle: Public Policy Lessons for Bank and Thrift Regulation. New York: Oxford University Press.

Wilmsen, Steven K. 1991. Silverado: Neil Bush and the Savings and Loan Scandal. Bethesda, Md.: National Press Books.

Yago, Glenn. 1991. Junk Bonds: How High Yield Securities Restructured Corporate America. New York: Oxford University Press. 